\title{
The Antecedents of Women Leadership in SMEs: The Malaysian Senior Female Managerial Perspective
}

\author{
Rohani Binti Mohamad Husain ${ }^{1} \&$ Li Xiao Xiao ${ }^{1}$ \\ ${ }^{1}$ Asia Pacific University of Technology and Innovation (APU), Technology Park Malaysia, Malaysia \\ Correspondence: Rohani Binti Mohamad Husain, Asia Pacific University of Technology and Innovation (APU), \\ Technology Park Malaysia, Bukit Jalil, 57000 Kuala Lumpur, Federal Territory of Kuala Lumpur, Malaysia. \\ E-mail: rohani@apu.edu.my
}

Received: November 7, 2015

Accepted: March 7, 2016

Online Published: April 18, 2016

doi:10.5539/ijbm.v11n5p179

URL: http://dx.doi.org/10.5539/ijbm.v11n5p179

\begin{abstract}
Leadership emphasis on leader abilities, personality traits, influence of relationships, cognitive versus emotional orientation and individual versus collective interests (Deanne \& Hartog, 2001).With the accelerate development of human civilization, women began playing indispensable leading roles in different social realm, particularly in business, society and political area. With women began playing increasing significant leading roles currently, it raised the influence of women's leadership in organization.

In this study, through the full research of female leaders and the influential factors of women leadership, by analysing the of female leaders and through the deep assessment of women leadership, it summarized the existing achievements made by female leaders, pointed out the common problem existed in women leadership as well, and found out the relationship between leadership effectiveness of female leaders and women leadership. In general, this study summed up the dimensions of leadership effectiveness of female leaders, then concluded how these dimensions influenced on female leaders in middle management level. This research will be conducted on the basis of women senior managers in SMEs in Kuala Lumpur.
\end{abstract}

Keywords: senior women leadership, SMEs in Malaysia, glass ceiling effect, job satisfaction, moral character, organisational behaviours

\section{Introduction}

It is the basis of this entire research and it is the overall background of the study, this chapter includes such as background, problem statement, research objectives, research hypothesis and theoretical framework. For the research, it is important to create a research problem and putting it into a research context. For the study of women leadership, previous researches and studies have found that there are close relationship between the dimensions of leadership effectiveness and women leadership (Stark \& Ely 2003).

\subsection{Problem Statement}

According to Mattis (2001) it shows the development of female leaders will have relative effect to the future development of women leadership. With the development of society, the knowledge and quality of female employees has greatly improved. Thus, the effectiveness of women leader has been increased at the same time. According to Pande and Ford (2011) it indicated that there were both positive and negative aspects in the attributes of female leaders. Researches also indicate that the attributes of female leaders will bring positive and negative influence to the leadership. Therefore, no matter what kinds of enterprises, they are trying their best to find out and understand the female leaders and the factors that affect their leadership.

Therefore, the problem to be addressed was what are the underlying factors associated with female leaders in senior management level that influence women leadership in SMEs, and it shows the imperative in this research. In shorts, women leadership is very important to the enterprises' further development, enterprises want to make it works more efficiently and further benefit the effectiveness of leadership. However, as noted by Tewfik (2011), there are problems and obstacles toward women's leadership that can be concluded as objectively business environment and social factors that influenced on women in leadership, such as the traditional concept to female, organization reject of female, lack of social support. In this study, the writer will main identify the subjective factors (dimensions of leadership effectiveness towards female senior managers) that influence on women's 
leadership; furthermore, this study will determine the most significant factors that affecting women's leadership in SMEs in Kuala Lumpur.

\subsection{Research Objectives}

Research objectives are the purposes and targets of the research project. The objectives are made logically. Firstly, the dimensions of leadership effectiveness will be identified and narrowed to the influential factors to women leadership. Then the effectiveness of each influential factor will be identified by the hypotheses testing and statistical analysis. Next the most influential factor that affects women's leadership will be found out. The three main objectives will lead the research to determine the most significant factors that influencing women's leadership in business performance.

$>$ To clarify the dimensions of leadership effectiveness towards female senior managers in SMEs.

$>$ To identify the effectiveness of each factor that affect women's leadership in senior management level of enterprises based on the previous research and further literatures.

$>$ To determine and evaluate the most significant factors that affect women leadership.

\subsection{Significance of the Research}

This paper attempts to identify the influence of female senior managers on the leadership in the enterprise management. It mainly focused on the research of female senior managers in SMEs, and future researchers will benefit from providing empirical parameters of leadership theory. In addition, the research will promote the organization's compliance with gender equality in the legal principles and business practices; it helps organization to recognise that women leadership can bring more economic benefits for the enterprise. Furthermore, it is important for organization to build a harmonious and fair working environment in Malaysia. The study helps to make organization reconsider and adjust the management strategy, determine gender diversity in leadership and provide same opportunities for both gender leaders to identify their potential abilities in workplace. The study of women's leadership is to enrich and improve the leadership studies. Through the study of women leadership, it can enrich and enhance the management of organization development and promote the overall leadership progress of society.

\subsection{Scope of the Research}

The scope is to identify the factors that influence on the women leadership in senior management level of corporation. The scope is narrowed down only among female leaders in senior management level in nine SMEs. Besides, the narrow scope helps data collection and statistics analysis and they are the perfect representative for the research on women's leadership. 200 female leaders will be randomly distributed questionnaires through online. Women leaders in senior management level and from totally nine SMEs in Kuala Lumpur will be prior represented by Sledgehammer Communications (2012), such as financial and accounting managers in Hong Leong Bank and Kuwait Finance House Berhad; cosmetics and healthcare services managers in Shahnaz Herbals and Slimming Sanctuary Sdn Bhd; hotel and hospitality manager in Royale Chulan Hotel; consumer service managers in Sunway Retail Group, Poney Company and PepsiCo and managers in Malaysian Insurance Institute.

\section{Literature Review}

\subsection{Women Leadership Theories}

\subsubsection{Gender Roles and Leadership Research}

The focus of this study is: whether the effectiveness of leadership behaviour exist differences based on the different characters of gender roles. One is defined as gender stereotypes forming by the prevailing socio-cultural expectations; the other is prejudice; it is common think that the masculine generally considered superior than femininity (Buddhapriya, 1999).

According to Heilman, Wallen, Fuchs, and Tamkins, (2004) male leaders believe that the success of the mid-level leadership has personality traits and attitudes more tend men; while women leaders thought that the success of the middle level leaders have the personality and attitude tend to the men and women both. 


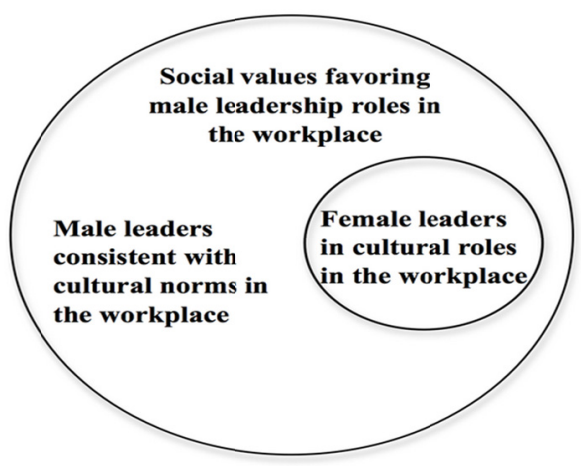

Figure 1. Counter cultural roles of women leaders in a masculine culture

Source: Adapted from Turesky, Cloutier \& Turesky (2011).

With the rise of feminism and the more important roles female play today, some studies have found that there are no big differences between men and women on the leadership role. In the contemporary global environment use changes as the characteristics, more and more studies have shown that women leaders scores than men in many indicators by colleagues, subordinates and superiors assessment. McKinsey Global has conducted survey in 231 private enterprises among 115,000 employees, from survey it found: enterprises with a large proportion of women senior executives, the organizational performance and financial results will be better; OECD (2012) has studied from 1992 to 2006 among 1500 enterprises in United States has found that, there is a strong positive correlation between the rate of return on assets and return on equity with "female executives". From 19 consecutive years' research to Wealth 500 companies, it found that the greater the proportion of women in management, the higher vitality of enterprises is.

\subsubsection{Ability of Female Leadership}

It did not make a distinction between man and woman on the ability of leadership from previous research, which always discussed in a same standard. There are few research specially focus on woman leadership. Refers to Brown and Irby (2001), it considers there exists a big difference between man and woman on cognitive capacity. Man have a talent on distinction, while, woman perform a strong ability on integration. According to Tong Zhao Ying (2004), the basic components of women leadership include technical capacity, alertness, aggressiveness, organizational capacity, the ability to create environment, and so on. According to Turkel (2008), he did a research on administrative competence of female leaders; the result indicates that female leaders have many advantages on leadership from many sides, which is necessary in the new economy era. Such as the ability on promoting vision, do not fear innovation, concentration on career, more emotional involvement in their job under the technical era, translate challenge to opportunity, attention on preference of customer, brave to prevail over all dissenting views, create fresh innovations and so on. The administrative competence of female cadres has its own characteristics except the common recognition, which includes forecasting capacity, decision ability, innovation capacity, synthetic ability, command capacity and so on (Connor, 2010). It can be divided into three levels that are base level which contains research ability, philosophy thing ability, ability of endure, commissioning ability, and collaboration capacity with other people, inter level which contains prediction and decision ability, social activity ability, capacity on talent development, ability to guide grass-roots work, and adaptability, and highest level which contains development and innovation ability.

\subsubsection{Advantage of Female Leadership}

According to Helgesen (1995) female leaders have outstanding traits such as: stable work pace; women leaders are more willing to accept work outside the scope of the conversation; female leader will not excessive immerse themselves in the daily management work, and they will actively participate in social intercourse; women will share information with others not only to subordinate but also spread out. The study found that compared to male leaders, female leaders have advantages in aspects like: communication, language, coordination, affinity aspects, emotional aspects, financial aspects and comprehensiveness (Bass \& Riggio, 2006). In addition, attention to detail, good at team building, toughness and high credit form the unique advantages of female leadership (Eagly, 2007). Besides, multiple tasks simultaneously, focusing on a variety of solutions and strong, forward-looking, practical and strong, inspirational, open and innovation, engrossed, good at guiding, clear decision-making, understanding and work in humane way, all these have been forming women's unique leadership style and leader 
Art (Buttell, 2010).

\subsubsection{Effectiveness of Leadership}

The understanding of leader effectiveness will be different due to the different point of view of researchers. According to Bass, B. M (1990), leadership effectiveness is an organization in the implementation of its basic task able to obtain the success: the reach of organization's objectives is the standard to measure leadership performance. According to Hartog, and Koopman (2001) leadership effectiveness is the reach of subordinate's satisfaction and organizational performance. As mentioned by Gordon (2002) the objective assessment of organizational performance, the objective assessment of the subordinate's attitude to leaders, as well as organizational trust, job satisfaction are measure of leadership effectiveness factors. However, concluded by many researchers, those three main factors can be settled as measurement index:

First, the impact results of leader behaviour activities to subordinates. For example: leader authority, organization performance, staff satisfaction, organization commitment, glass ceiling effect, organisation citizenship behaviours and organizational trust. Second, the achievement of organizational goal can be settled as measurement index. For example: earning rate, production and product pass rate. Third, the awareness of subordinate to leader can be settled as measurement index. For example: separation rate, worker absenteeism rates and subject indicators from questionnaires.

Through analysis of the literature on leadership effectiveness, combined with leadership performance indicators required in this research. In the study, the evaluation indicators of leadership performance will identify from the female leaders' point of view, discuss from four dimensions based on leadership effectiveness like: glass ceiling effect; job satisfaction; moral character and organisation citizenship behaviours.

According to Manning and Curtis (2003), leadership effectiveness is an overall target including the following aspects:

1) Effectiveness of decision-making performance. Decision-making is the primary function of leadership. The correctness decision will determine target direction of leadership activities and organizations activities.

2) Effectiveness of employment. Effectiveness of employment refers to the effectiveness of selecting and using people in the leadership activities. It not only related to the effect the goals to the organization, but also directly affects the organization's social value of its existence.

3) Effectiveness of Work. It is the efficiency that achieved by leaders with processing various affairs. Leaders' functional activities are mainly described as dealing and problem-solving, for example: organization and command, coordination and incentive.

4) Effectiveness of time. Time performance is a measure of a leader in management and usage of time. Leaders' time performance is related to the organization operation, so it is important to minimum time wasting. Besides, seize the opportunity and focus on the business effectiveness is also necessary for leaders.

5) Effectiveness of organisation's overall contribution. The effectiveness of organisation's overall contribution refers to the degree of realization the organisation objectives. Leadership effectiveness can not only reflect in the individual departments work, more importantly, is can reflected in the overall work and overall contribution. Thus, the realization of the overall objective is the most important criteria to measure the leadership effectiveness in organization.

Furthermore, to make female senior managers realize that the tendency of female advancement in organisation can increase the leadership effectiveness of female leaders. The more coincidence of female traits with senior leaders, the higher confidence of women in management role will be. It will develop the stronger motivation for women to advancement to top management level, and make higher effectiveness of women in higher management role rather than in senior management role.

A research on leadership effectiveness is the strategic approach to leadership development. The dimensions of leadership show a wide range of leadership characteristics and skills. The leadership dimensions can be the basis for leaders' assessment and evaluations in organization, the essential purpose is to provide perception and information to improve leadership effectiveness (Reeves, 2006). The analysis of leadership effectiveness is designed to increase the effectiveness of women in leadership roles. The dimensions are particularly important for leaders. Glass ceiling, job satisfaction, moral character and organisational citizenship behaviour are the typical dimensions for leadership. Besides, there are other eight dimensions approaches to determine the leadership style in organisation which are also important to the effective functioning of leaders in organisation. For example: Pioneering, Energizing, Affirming, Inclusive, Humble, Deliberate, Resolute and Commanding 
(Sugerman, 2011). In short, those four dimensions of leadership mentioned in this study are not only improving effectiveness of leadership, but also a suggestion that can identify the most influential factors to women's leadership.

\subsection{Research Approach of Women Leadership}

The effectiveness of leadership will help to determine the factors which influence on women leadership, for example, the effectiveness of leadership are including dimensions as below:

\subsubsection{Glass Ceiling Effect}

Glass Ceiling generated from 1986, it was first used in a study of "women in enterprise" by Hymowit \& Schellhandt (1986) from The Wall Street Journal. At the beginning, in the mainstream of society in Europe and the United States, the immigrants especially Asians only act as low-level positions, or hard to promotion when achieve a relatively high positions, thus they cannot enter the core decision-making level. Like the glass ceiling, it can be seen while it is difficult to break through the obstacles. Now it more refer to obstacles that exist in the organizational structure of invisible but real, which can be the obstacle for women's advancement opportunities. More women break through the glass ceiling, but leadership roles elusive.

After a series of experiments, Eagly and Steffen (1986) has found that professional roles with hierarchical social structure has caused by the different gender roles. As stated by Van Vianen, A. E. M., \& Fischer, A. H. (2002), organizational culture is developed and dominated by the male senior managers, thus reinforcing the existence of a glass ceiling.

The study found that the personal characteristics, the degree of role conflict, as well as the company's corporate culture affects women as corporate executives. According to Lemons (2003), it has used middle management women as objects and found the promotion barriers will affect career development, life satisfaction and job satisfaction, and the relationship between career job satisfactions. In short, the glass ceiling effect will not only affect women's career development, but also affect their work and life satisfaction, thus will also affect the work performance of women, and this is kind of a crisis for businesses.

About the impact of gender diversity in management on employee perception of the glass ceiling, according to Koneck (2006) through empirical analysis, the higher proportion of women in senior management are, the lower perception of glass ceiling are. As mentioned by Daft, R. L (2008), gender diversity management promoted fairness and female career barrier in empirical research, gender diversity management can make women feel more equitable for advancement. In other words, for women in workplace, the more proportion of women in management, the more promotion fair women will feel, and their perception of the glass ceiling is less obvious in workplace.

Malaysia is a diverse country with a more inclusive socio-cultural. Despite the women has been improved in the workplace, however, a larger proportion of women still suffer glass ceiling in workplace, only a small number of women can able to break through the taboo (Abdul, Syed, \& Basir, 2011). While, other reasons are trying to explain this phenomenon, such as the old social system, socio-cultural, gender stereotypes and so on.

As reported by Murray (2010), today women still face a glass ceiling. In the survey of Institute of Leadership and Management (ILM), it finds $73 \%$ of female managers still feel there are barriers for advancement, while only $38 \%$ of men believed there is a glass ceiling in working place. The formation of the glass ceiling, there are two main factors. First is the gender stereotype. Women were considered to lack of management personality incompetent senior management positions; Second, organizational systems design. The reasons for the phenomenon of the glass ceiling, as reported by Snowdon (2011), the Ambition and Gender at Work report says women's management aspirations lag behind men's. The scholars have different opinions and broadly classified into two categories: nativism, that women are born docile, friendly, sharing temperament is not suitable of being a leader, women will be less in leadership skills and management; acquired theory, between family and career, women's choice is often biased towards the family, and women cannot devote more energy to work. Barriers for women to promotion, the reasons including: deep stereotypes, women's participation in decision-making management level is too risky, lack of career planning and appropriate position, women are excluded from male colleagues and male deliberately against female (Snowdon, 2011).

\subsubsection{Job Satisfaction}

According to the earliest research on job satisfaction began in the 1930s by Hoppock (Hoppock, 1935 Kornhauser \& Sharp, 1932; Roethlisberger \& Dickson, 1939), he believes that job satisfaction is the satisfied feeling to the environment from two aspects: psychological and physiological, and they also the reactions of the workers to work scenarios. 
Some studies focus on the relationship between employee satisfaction and employee turnover. Several studies have investigated the relationship between employee satisfaction and customer satisfaction especially in service-oriented enterprise. Spector (1997) starting from the social environment and the psychological motivation of the employee, think that the social and technological environment, self-realization, recognition are the main influential factors of job satisfaction.

Foreign scholars have conducted a lot of research on the main factors of affecting job satisfaction. Hoppock thought that there are factors may affect job satisfaction include: Fatigue, monotonous work, working conditions, and leading style. He is more from the point view of job content, working conditions and material properties to determine the impact of employee job satisfaction factors. Besides, there are relationships between employee job satisfaction and employee production, employee job satisfaction will affect employee productivity (Saari \& Judge, 2004). As noted by Eikelenboom (2005), who has conducted the study of 200 employees from the joint venture, there are seven main factors affect employee job satisfaction, personal factors, leadership factors, work characteristics, working conditions, wages and benefits, salary, the colleagues relationship. From the salaries and benefits to the opportunity for promotion, gender diversity of employee job satisfaction, it including the four categories of factors: the work, the company, individual employees and the environment ( $\mathrm{Tu}, 2006)$.

\subsubsection{The Influence of Female Leader Management to Employee Job Satisfaction}

As noted by Wharton and Baron (1991), they have discussed the influence of cancelling occupational discrimination to male. They found that compared with those in a working environment, no matter it mainly consist of men or women, men will show a significantly lower job satisfaction and lower self-esteem as well as significantly higher work depression in both gender working environment. In other words, to increase gender diversity in the work environment which means increase the proportion of female employees will reduce job satisfaction of male employee. But whether it will result in the same consequences on the increasing of the proportion of women in management, foreign scholars have not studied yet.

However, some researchers have stated that there is no insignificant relationship between leadership principles and employee job satisfaction (Mehrotra, 2005). In his study, he found that there were obvious differences in leadership on the basis of managers' different demographic characteristics; and also, the study found that there were obvious differences in job satisfaction due to different demographic profiles of employees. This finding was against to the study by Naseen in 1986, who found that there is a positive relationship between leadership style and job satisfaction.

Vroom thought that job satisfaction is the individuals satisfied with the status of their jobs and the value orientation of the job role in 1964. Smith Kendall and Hulin in 1969 pointed out that job satisfaction is a pleasurable feeling when individual assessment of their work and the work experience; Locke agree with the view of Smith; in 1972, Price has defined job satisfaction as: in an organization, the members who have the positive emotional orientation to their role, that mean employees feel satisfaction; otherwise they dissatisfied with their job (Tu, 2006). It will also lead a negative attitude towards work. From those it can be found that organization can monitor the operational status by investigate job satisfaction of employees, and it will help to discovery and ruled out the problem in time. Through job satisfaction survey to understand the idea of female staff and identify lack of management, thereby arousing the enthusiasm of the staff and improving the organization management (Aziri, 2011).

\subsubsection{Moral Character}

The moral quality refers to women leaders with the basic moral and personality traits, including moral qualities and personal conduct. The first factors affect the leadership is outstanding personal qualities. In the modern enterprise management, managers and managed objects have equal legal status, relations between the two sides are equal and cooperative, two-way choice as well (Weber, 1998). However, due to the differences of the division of labour, there exist status of manage and be managed. Thus managers must have good moral character, through outstanding moral characters influencing managed objects, making managers proactive and efforts up from the thinking and actions (Emrich, 1999).

Moral leadership, according to Chmiel (2001), leader are not only the commander for group and organization activities, while also accepting a subordinate moral examine and psychological evaluation, it is the guide and demonstrators for subordinate concepts and behaviour. In recent years, some Western well-known enterprises such as Enron, Arthur Andersen, WorldCom, ClobalCrossings, Adelphia and other companies have bankrupt or serious declined due to the leaders moral problem, it has aroused the concern of Western scholars on the ethical considerations of business leaders, and put forward the concept of corporate moral leadership (Friedman, 2001). 
As mentioned by Ciulla, J. B (2004), integrity moral character is the only absolute condition that leader should have. Leadership is a moral charm. The basis of the influence comes from the moral qualities of the leader. Ethics is considered as the heart of leadership. Famous management researcher Peter Drucker once said: "If the leader lack integrity moral, then, no matter how much he is knowledgeable, talented, accomplished, it can also cause significant losses (Ciulla, 2004).

The Italian Jewish economist Pareto develops a famous Lorenz curve, combined with corporate management that: $20 \%$ leaders create $80 \%$ performance for the company, $5 \%$ of the middle-high level direct impact on the $51 \%$ of their income (Daft, 2008). For example, assume that the chief leaders of the company or the middle-high level in company have moral characters; the company will be ruined soon. This is a complex problem, in fact, the root of the problem is the moral characters of the business leaders.

Strong group thought is important for leadership. Public benefit heart and self-interest heart is a pair of opposite concepts, people are aware of the meaning of self-interest and many people are affected by this (Mele, 2011). However, as a manager, she has to have strong group thought and can use public benefit ideological as the standard for measure management behaviour. Only by this she is capable to consider, balance and concern all parties interests, get the more endorsement and support and thereby greatly enhancing the leadership effectiveness.

\subsubsection{Women Are More Moral Than Men}

Good moral character is the most important and core competitiveness for female leadership. Leaders with excellent moral character always broke out the positive power from the heart. In other words, good moral can promote leadership development constantly forward. Speak of moral leadership, it should first have the loyalty, dedication, honesty, thrift and sense of responsibility; they care about subordinate, care about customer and care about the development of the organization; they treat work motivated, enthusiastic, hard-working and have team spirit as well; they are proactive and have an attitude of gratitude with to help the organization in the development, production and management (Scott, 2008).

A plenty of studies demonstrate that men have lower moral standards than women. For example, men are more likely to minimize the consequences of improper handling moral compared than women (May, 2012). When men must use strategy or scheme to prove or defend their masculinity, they are willing to compromise with moral standards. A number of researches shows, men usually set lower moral standards than women. Besides, as reported by May (2012), men's moral judgments are inconstant and usually choosing to maximize their own advantage first especially in some negotiation process; when necessary for personal gain, moral misconducts were acceptable. In opposite, women made moral judgments consistently and followed by standard almost in all perspectives; according to Furness (2012), even when the moral choice has obvious conflicts of personal interest, it turns out that women still insist on maintain their moral standards.

\subsubsection{Organisational Citizenship Behaviour}

Barnard in 1938 he believed that "the organisation is a combination of cooperative efforts, regardless of any organisation," willingness to cooperate between members is essential. Katz in 1966 thought that if an organisation wants to ensure effective operation and high performance, organisational citizenship behaviour is essential for organisation. According to Schneider and Smith (2004), Organ, Podsakoff and MacKenzie in 1983 have proposed a concept of "organisational citizenship behaviour" based on the study. After classification of organisational citizenship behaviour, Smith in 1983 pointed out that the organisational citizenship behaviour including "helping behaviour" and "usually compliant behaviour. In that year, Bateman and Organ propose the concept of organisational citizenship behaviour based on previous studies. Organisational citizenship behaviour is a spontaneous, although not formal but real need, and can effective improve overall organisational behaviour. He has officially defined organisational citizenship behaviour as: it has not been clearly affirmed in salary system of organisation while the sum of the operating behaviour could conducive to the organisation (Schneider \& Smith, 2004). Organisational citizenship behaviour includes the initiative to work to help my colleagues, to express their views and to participate in group activities, promote corporate image, self-study, participate in social welfare activities, enterprise resource savings to keep the workplace clean, maintain harmony (Farh, Zhong, \& Organ, 2004).

\subsubsection{Significance of the Study}

According to Podsakoff and Mackenzie (2000) it has reviewed literature of organisational citizenship behaviour. They pointed out, academia mainly research the importance of employees organisational citizenship behaviour from the following two aspects: the influence of employees organisational citizenship behaviour managers in 
assessing employee job performance and employee remuneration as well as job promotion; the influence of employees organisational citizenship behaviour on business efficiency and performance. Organ, Podsakoff, and Mackenzie (2006) pointed out the importance of employees organisational citizenship behaviour as below: it can improve the working efficiency of colleague and management; it allows managers more effective use of various resources; it help to enhance team spirit, team members or managers do not have to spend a lot of time and effort to resolve conflicts between employees; it contributes to coordinate the team work between the team members; it helps to enhance the enterprise's ability; it helps to attract and retain good employees; It improves stability of business performance; it can improve the ability of enterprises to adapt to environmental changes (Organ, Podsakoff, \& Mackenzie, 2006).

Many scholars believe that the employees from service enterprises their organisational citizenship behaviour will affect customer perception of service quality. The American academics Elizabeth point out, employees organisational citizenship behaviour consistently matches the behaviour of employees services which discussed by service management scholars; Korean scholars Hee and American scholars Jaebeom thought that, the organisational citizenship behaviour of service personnel will directly affect customer perception of service quality; Spanish scholars Carmen on the empirical findings of bank indicates that staff organisational citizenship behaviour will directly affect customer perception of service quality and customer satisfaction (Bronwynne, 2007).

\subsubsection{Antecedent Variables of Organisational Citizenship Behaviour}

There are many concepts about antecedent variables of organisational citizenship behaviour, it mainly reflected in the two aspects as individual's attitude and motivation, for example: job satisfaction, organisational justice, organisational commitment, leadership support, career satisfaction and organisational trust (Podsakoff \& Mackenzie, 2000). The most research results indicate that job satisfaction, organisational justice and organisational commitment are positively correlated with organisational citizenship behaviour. The variables results by most scholars of organisational citizenship behaviour study mainly focus on organisational performance, and prove that there is a positive correlation between organisational citizenship behaviour and organisational performance.

Summarized scholar researches, about antecedent variables of organisational citizenship behaviour, according to Organ, Podsakoff, and MacKenzie (2006) there are four main aspects: First, personal qualities. From the definition of organisational citizenship behaviour, it is a spontaneous, the role of outside and non-reward system directly expressly recognized organisational behaviour, and study influential variables more biased individual characteristics in the study. About the research of personal qualities, it including a sense of fairness, job satisfaction, organisational commitment is considered to be the important motivation of organisational citizenship behaviour. In addition, there are correlation between personal ability and organisational citizenship behaviour as well as personality differences and organisational citizenship behaviour (Mester, 2003). Such as job title, education, independent and psychological contract. Second aspect is task qualities. The results found that the task feedback, task routine and tasks internal satisfaction has the significant correlation with organisational citizenship behaviour. Third aspect is organisational characteristics. Organisations with different characteristics have differences inspire and influence organisational citizenship behaviour. The study found that there is a significant correlation between organisational citizenship behaviour and organisational characteristics such as organisational perception, organizational culture and team psychological safety characteristics (Tayyab, 2005). Next is Leadership qualities. The influence of different leadership behaviour to organisational citizenship behaviour is significant. The study found that there are very significant correlation between leadership with subordinates exchange activities and organisational citizenship behaviour, and this relationship can adjust by subordinates exchange conscious (Joseph \& Winston, 2005). In addition, the high-performance expectation and the support of the leadership behaviour also have correlation between organisational citizenship behaviour, and all these need further research. Organ combined "peripheral performance" concept and put forward: although organisational citizenship behaviour cannot provide effective help for performance, but it provide continual improvement for the formal, informal group environment in organisation, and facilitate organisation performance (Organ, Podsakoff, \& MacKenzie, 2006).

\subsubsection{The Influence of Female Leader Management to Organisational Citizenship Behaviour}

According to Organ, Podsakoff, \& Mackenzie (2006), gender is the very important factor to determine organisational citizenship behaviour. Scholars are starting to carry out related research later, and it turns out that organisational citizenship behaviour showed significant differences in gender and women compared to men will showed more organisational citizenship behaviour. 


\section{Research Methodology}

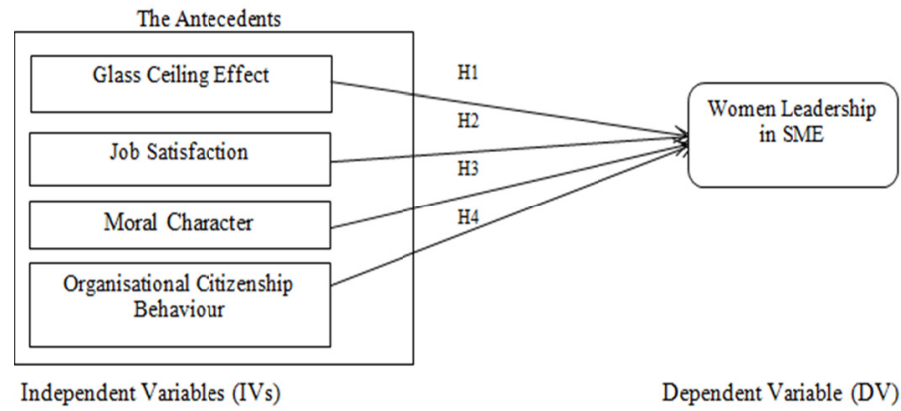

Figure 2. Theoretical framework

Figure 2 shows the relationship between the independent variables and the dependent variable, it shows the four independent variables of female senior managers which have influence on women's leadership in SMEs. The primary research and hypothesis testing will be conducted based on this theoretical framework.

\subsection{Research Hypothesis}

Hypotheses will be figure out according to the theoretical framework. The Hypotheses will be according to research objective to identify the effectiveness of each factor, it will help to ensure the relationship between the independent variables and the dependent variable. The following are the detail of research hypotheses:

H1: The glass ceiling effect of female senior managers will bring negative influence on women's leadership

H2: The job satisfaction of female senior managers will be no influence on women's leadership

H3: The moral character of female senior managers will be the most significant influence factor on women's leadership

H4: The organisational citizenship behaviour of female senior managers will be the second important influence factor on women's leadership

This table of research hypothesis can show the relationship between independent variables and dependent variable. In addition, the relationship will be further identified by hypothesis testing and statistical analysis.

\section{Data Collection Method}

\subsection{Secondary Data}

Secondary data is recorded from the previous studies in the literature review part. The related articles and journals will be selected, such as Psychology of Women Quarterly, Journal of Management Development, and Journal of Social Issues. These resources mainly come from the resource suppliers such as Harvard Business Press, Emerald, and SAGE. The related books such as Developing Women Leaders which written by Valerio (2011) are also used as reference.

It is important to provide information about the research topic and prove the variables of leader effectiveness and women leadership. The information and data are collected from books, journals, magazines, newspapers and other online books based on the academic purpose of the projects. However, it is not sufficient to meet the specific targets by use secondary data source only, the limitation is also obvious. In short, secondary research is not enough for data collection and the primary research should be conducted in order to further identify and support the findings.

\subsection{Primary Data}

Questionnaire survey will be used for primary data collection. Based on research objective and theoretical framework design, questionnaires were administered to female senior managers from SMEs in Kuala Lumpur. As noted by Greasley (2008), SPSS is a program used for statistical analysis. It allows for in-depth data access and preparation, analytical reporting, graphics and modelling. By using descriptive analysis, correlation coefficient and chi-square test for data analysis, it will further elaborate and demonstrate the basic ideas and viewpoints, and ensure relation between attributes of leader effectiveness and women's leadership to draw final 
conclusions.

The primary data collection will be collected from distributing questionnaires. The questionnaires will be stratifying structured, the design will be terse and concise and all will be close-ended questions; respondents will be willing to fulfil questionnaires in an easy way: by ticking certain choices. Questionnaires will be email to relevant female managers and can be completed within ten minutes. However, the answer can be less accuracy due to lack of direct communication and observation with the respondents.

\subsection{Data Analysis Method}

\subsubsection{Quantitative and Qualitative Research}

Quantitative research usually use the form of the data, make stringent requirements on research rigor, objectivity, value neutrality in order to get an objective fact. Quantitative analysis is the analysis of quantitative characteristics, the relationship of number and the changes of number. Its function is to reveal and describe the interaction and the development trend of the research phenomenon (Woods, 2006).

Qualitative research is an exploratory research method. The purpose is to determine the problem and provide a deeper understanding and awareness, use qualitative analysis to define the problem or find a way of handling problems (Berkwits \& Inui, 1998).

Based on this project's situation, quantitative research would be more suitable to collect the necessary data from the actual related activities; according to quantitative research concept, by establishing assumptions and determine a causal relationship of variables, and then using some of these variables tested tools for measurement and analysis, in order to test hypotheses and consistency of findings, and verify the most influential factors of women leadership in Malaysia.

\subsubsection{Pilot Test}

Based on Morgan, Krueger, and King (1998) the reliable and goodness of the data are also rely on the measurements, the pretest will be undertaken in order to make respondent understanding of question meaning; make sure response categories are appropriate and questions are clarity; make sure instructions are adequate and data capture are effective. The aim of the pilot test is to identify question design and make effective operational procedures tested as well as assurance more meaningful and accurate data.

There were 20 people which including my lecturers and my classmates in APU participated in the pilot survey, 16 of them participated in the survey and all of them returned feedback to me about the survey. It was extremely helpful for the writer completing the survey for this dissertation.

\subsection{Sampling Techniques}

The stratified random sampling method will be used to determine the sample size of this research. The target group will be female senior executive from different SMEs in Kuala Lumpur. The female leaders can be stratified and based on the demographic profile such as age; education background; marriage status and working years and enterprise. Due to the diversification of corporations, female leaders are come from different working environment. The target female managers can be from different department. The results of survey will be more comprehensive that target group with different age, department and working experience in corporations. The target female managers are including financial and accounting managers; human resource managers; medical and health services managers; hotel and hospitality managers and social community service managers. The questionnaires will be distributed to total 200 female senior managers including: 20 managers from Hong Leong Bank and 20 managers from Kuwait Finance House Berhad; 20 managers in Poney Company and 30 managers in PepsiCo; 30 managers in Shahnaz Herbals and 20 managers in Slimming Sanctuary Sdn Bhd; 20 managers in Royale Chulan Hotel; 20 managers in Sunway Retail Group and 20 managers in Malaysian Insurance Institute. The primary sample size is total 200 female leaders in senior management level from nine different SMEs in Kuala Lumpur. Yet, only 100 effective questionnaires will be chosen and conducted an accurate statistics analysis in chapter 4.

There are differences and variability between layers of questions. Systematic random sampling method will be used to select the questionnaires respondents in different corporations, and it can be more accurate to getting data by female leaders from different corporations. The propose of this survey is not only shows the relationship between the attributes of leader effectiveness and women's leadership, but also determine the most influential factors that affect women leadership in corporations. The stratified random sampling method is not only represent the quantity of respondent, but also represent the critical viewpoint for the study. It will be the representative of the general considering and perception toward women leadership among female managers in 
Malaysia.

\subsection{Questionnaire Design}

Questionnaire will be settled based on the four variables: glass ceiling effect, job satisfaction, moral character and organisational citizenship behaviour as well as the dependent variable: women's leadership. The questionnaire research will be conducted and the quantitative data which include frequencies, means and standard deviations are necessary for this primary research. The questionnaire research will be conducted in SMEs that located in Kuala Lumpur. There are total 24 questions included and all close questions, respondents can make choice among alternatives within 10 minutes.

\subsection{Rationale of Survey Questions}

Simple quantitative analysis is to make some simple analysis to the questionnaire results, such as the use of percentage, mean frequency analysis. There will be two sections included in the questionnaire. Section 1 will be the demographic questions of female leaders, such as age, education level and working years. Section 2 is going to identify the relationship between dimensions of leadership effectiveness and women's leadership. Each attributes will be settled with questions in section 2. All the measurements will be based on the Five Points scale method in section 2. Section 3 is going to identify the most influential factor of women's leadership. The questionnaires will be designed as below:

Simple answer tick " $\sqrt{ }$ ";

1. Tick " $\sqrt{ }$ " the answer

2. Five points Scale

\begin{tabular}{llllll}
\hline Question & Strongly Disagree & Disagree & Neutral & Agree & Strongly Agree \\
\hline & 1 & 2 & 3 & 4 & 5 \\
\hline
\end{tabular}

\section{Section One:}

Table 1. Items of the demographic characteristics

\begin{tabular}{l}
\hline 1. Age \\
\hline 2.Marriage status \\
3. Education level \\
4. Years of being leader in corporation \\
5. Enterprise type \\
6. Perception of women leadership \\
\hline
\end{tabular}

They are demographic questions for target female leaders. The questions help to gather demographic data and can be used to correlate responds among different groups of participants. Respondents can chose answer by tick " $\sqrt{ } "$ the answer.

\section{Section Two:}

Table 2. Items of glass ceiling effect

\begin{tabular}{l}
\hline 1. Male staff have much more chances and faster speed for promotion \\
\hline 2. Women are more difficult to develop their career \\
3. Gender is the barrier to promotion \\
4. I believe glass ceiling effect will have an negative influence on women leadership \\
\hline
\end{tabular}

Glass ceiling effect were mentioned and adapted by Burke and Mattis (2007). The questions are based on the cognitive evaluation towards gender promotion decisions in working environment, such as 'male staff has faster speed of promotion'. The form of scoring uses five points. 
Table 3. Items of job satisfaction

\begin{tabular}{l}
\hline 1. I satisfied with the current job \\
\hline 2. I think I am rewarded equally as men on managerial positions \\
3. I think job satisfaction will have no influence on women leadership \\
\hline
\end{tabular}

The questions referred to Pitts et al. (2006), to measure the Job satisfaction by female leaders. There are only two questions 'satisfied with the job or not'. The form of scoring uses five points. The higher point means participants are more satisfied with the job.

Table 4. Items of moral character

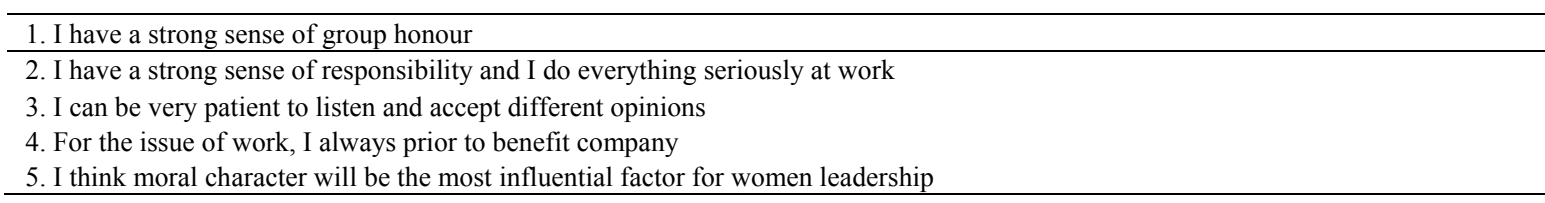

The viewpoint by Scott (2008) will be adapted and used to measure the Moral character in this research. The measurements mainly show whether the moral characters influence the leadership. The form of scoring uses five points.

Table 5. Items of organisational citizenship behaviour

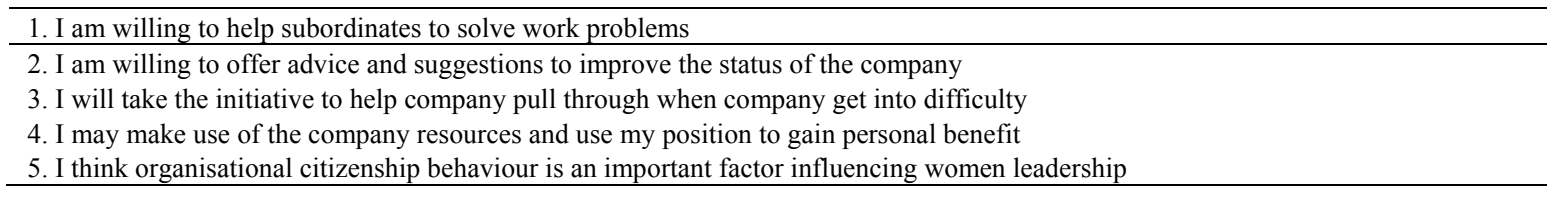

According to Vondey, M (2006), organisational citizenship behaviour was proposed and related to women leadership. The organisational citizenship behaviour acts as one of the dependent variable. Therefore, questions were settled based on organisational citizenship behaviour which will reflect the measurement of leader effectiveness of female. There are five questions such as 'willing to help subordinates to solve work problems'. The form of scoring uses five points.

\subsection{Analysis of Findings}

SPSS statistical tool will be used to collect and analyse the primary data. Followed analyses and testing will be conducted with the findings: 1). Descriptive analysis is used to determine the frequency distribution of the four dimensions of leader effectiveness; 2) Chi-square test will be used to identify relationship between independent variables and dependent variables. 3). In order to find out whether there will be relationship between independent variables, Correlation coefficient can be used to test the relationship between independent variables (Shannon, 2000).

The data analysis will be shown in frequency tables, graphs or charts. The finding will clearly show criteria evaluation of how leadership effectiveness affecting women leadership and find out the most significant factor that affect the women leadership in SMEs in Malaysia.

\section{Results of Data Analysis}

\subsection{Reliability of Data}

For the questionnaire, the total 24 questions have been distributed to 200 participants and only 100 effective questionnaires will be selected, the reliability of data will reflect the consistency and stability of questionnaire. Cronbach's Alpha method can be used to test the data, which is a reliability coefficient. Cronbach's Alpha is usually ranged from 0 to 1 ; the closer figure is to 1 , the higher consistency, reliability and validity of the data. The following table will show the result of Cronbach's Alpha by using SPSS. 
Table 6. The reliability analysis on glass ceiling effect

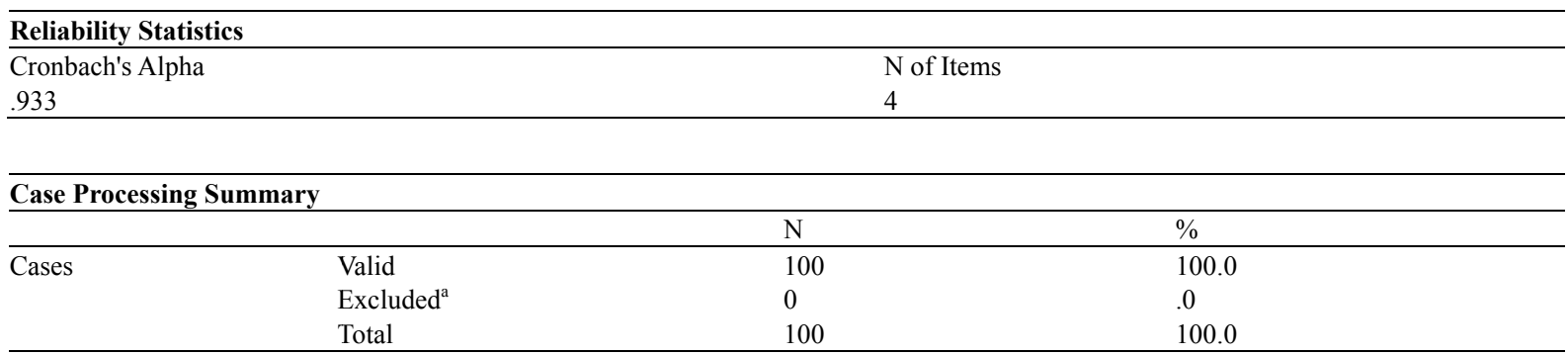

a. Listwise deletion based on all variables in the procedure.

\begin{tabular}{|l|l|}
\hline Cronbach's alpha & Internal consistency \\
\hline$a \geq 0.9$ & Excellent \\
\hline $0.8 \leq a<0.9$ & Good \\
\hline $0.7 \leq a<0.8$ & Acceptable \\
\hline $0.6 \leq a<0.7$ & Questionable \\
\hline $0.5 \leq a<0.6$ & Poor \\
\hline$a<0.5$ & Unacceptable \\
\hline
\end{tabular}

Figure 3. Performance for Cronbach's alpha coefficient

Source: Adapted from Alpha Coefficient (Cronbach, 2004).

It is clear to show that the result will be good when $\alpha$ is between 0.8 and 0.9. The result of Cronbach's Alpha on Glass ceiling effect is 0.933 , which can be proved that the questionnaire is extremely confidential. The valid data of collected 100 questionnaires are $100 \%$ which means the questionnaires can be used confidentially.

Table 7. The reliability analysis on job satisfaction

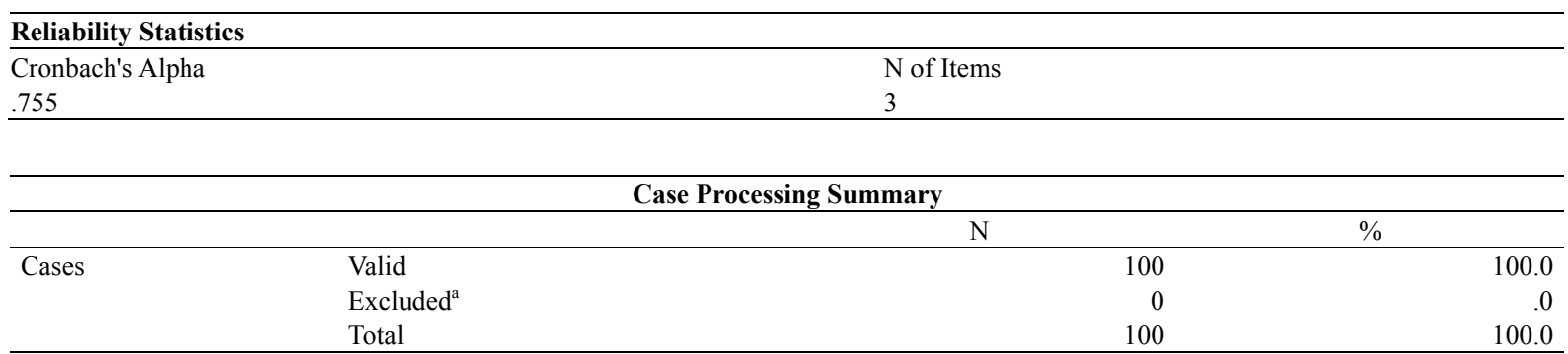

a. Listwise deletion based on all variables in the procedure.

\begin{tabular}{|l|l|}
\hline Cronbach's alpha & Internal consistency \\
\hline$a \geq 0.9$ & Excellent \\
\hline $0.8 \leq a<0.9$ & Good \\
\hline $0.7 \leq a<0.8$ & Acceptable \\
\hline $0.6 \leq a<0.7$ & Questionable \\
\hline $0.5 \leq a<0.6$ & Poor \\
\hline$a<0.5$ & Unacceptable \\
\hline
\end{tabular}

Figure 4. Performance for Cronbach's alpha coefficient 
It is clear to show that the result will be good when $\alpha$ is between 0.8 and 0.9. The result of Cronbach's Alpha on Job satisfaction is 0.755 , which can be proved that the reliability of questionnaire is acceptable. The valid data of collected 100 questionnaires are $100 \%$ which means the questionnaires can be used confidentially.

Table 8 . The reliability analysis on moral character

\begin{tabular}{ll}
\hline Reliability Statistics & \\
\hline Cronbach's Alpha & N of Items \\
.924 & 5 \\
\hline
\end{tabular}

\begin{tabular}{llrr}
\hline Case Processing Summary & & & \\
\hline \multicolumn{1}{c}{ Cases } & & $\mathrm{N}$ & $\%$ \\
& Valid $^{\mathrm{a}}$ & 100 & 100.0 \\
& Excluded $^{\mathrm{a}}$ & 0 & .0 \\
& Total & 100 & 100.0 \\
\hline
\end{tabular}

a. Listwise deletion based on all variables in the procedure.

\begin{tabular}{|l|l|}
\hline Cronbach's alpha & Internal consistency \\
\hline$a \geq 0.9$ & Excellent \\
\hline $0.8 \leq a<0.9$ & Good \\
\hline $0.7 \leq a<0.8$ & Acceptable \\
\hline $0.6 \leq a<0.7$ & Questionable \\
\hline $0.5 \leq a<0.6$ & Poor \\
\hline$a<0.5$ & Unacceptable \\
\hline
\end{tabular}

Figure 5. Performance for Cronbach's alpha coefficient

Source: Adapted from alpha coefficient (Cronbach, 2004).

It is clear to show that the result will be good when $\alpha$ is between 0.8 and 0.9. The result of Cronbach's Alpha on Moral character is 0.924 , which can be proved that the questionnaire is extremely confidential. The valid data of collected 100 questionnaires are $100 \%$ which means the questionnaires can be used confidentially

Table 9. The Reliability analysis on Organisational citizenship behaviour

\begin{tabular}{ll}
\hline Reliability Statistics & \\
\hline Cronbach's Alpha & N of Items \\
.940 & 5 \\
\hline
\end{tabular}

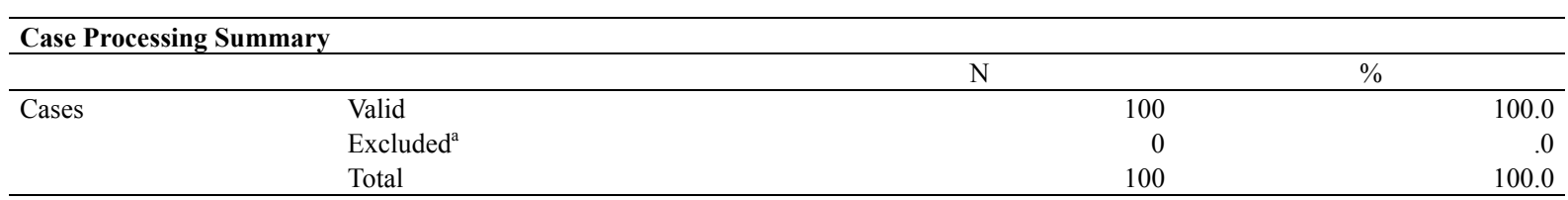

a. Listwise deletion based on all variables in the procedure.

\begin{tabular}{|l|l|}
\hline Cronbach's alpha & Internal consistency \\
\hline$a \geq 0.9$ & Excellent \\
\hline $0.8 \leq a<0.9$ & Good \\
\hline $0.7 \leq a<0.8$ & Acceptable \\
\hline $0.6 \leq a<0.7$ & Questionable \\
\hline $0.5 \leq a<0.6$ & Poor \\
\hline$a<0.5$ & Unacceptable \\
\hline
\end{tabular}

Figure 6. Performance for Cronbach's alpha coefficient

Source: Adapted from Alpha Coefficient (Cronbach, 2004). 
It is clear to show that the result will be good when $\alpha$ is between 0.8 and 0.9. The result of Cronbach's Alpha on Organisational citizenship behaviour is 0.940 , which can be proved that the questionnaire is extremely confidential. The valid data of collected 100 questionnaires are $100 \%$ which means the questionnaires can be used confidentially.

\subsection{Summarizing Data}

\subsubsection{Descriptive of Data}

Descriptive analysis will indicate the result of frequency distribution for demographic profile and four variables. This method is more used for demographic section to clearly see the distribution of each category, such as age, marriage status, education level, working experience and enterprise.

\section{- Age}

Female senior managers' age has been arranged as four categories that are up to 30-year-old, 30-39-year-old, 40-49-year-old, and 50+-year-old. Age frequency will show the female senior managers' age distribution from different SMEs in Kuala Lumpur. The following descriptive analysis will display the distribution of different ages from classified age group.

Table 10. Descriptive analysis of Age
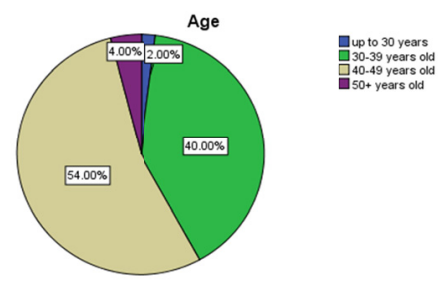

\begin{tabular}{|c|c|c|c|c|c|}
\hline \multicolumn{6}{|l|}{ Age } \\
\hline & & Frequency & Percent & Valid Percent & Cumulative Percent \\
\hline \multirow[t]{5}{*}{ Valid } & up to 30 years & 2 & 2.0 & 2.0 & 2.0 \\
\hline & $30-39$ years old & 40 & 40.0 & 40.0 & 42.0 \\
\hline & $40-49$ years old & 54 & 54.0 & 54.0 & 96.0 \\
\hline & $50+$ years old & 4 & 4.0 & 4.0 & 100.0 \\
\hline & Total & 100 & 100.0 & 100.0 & \\
\hline
\end{tabular}

The above table shows the distribution of different ranges of female senior managers' age from different SMEs in Kuala Lumpur. The range of "up to 30-year-old" takes $2 \%$ ( 2 out of 100 respondents) of all the respondents. Most female senior executives" age belongs to the range of "30-39-year-old" and "40-49-year-old". There are 40 female senior executives (40\%) in the range of "30-39-year-old", while the percentage of respondent is $54 \%$ who range between 40 to 49 years old, when a leader considered more mature and has already been exposed to team leadership roles. There are only $4 \%$ female senior managers, who are in the range of " $50+$ year-old".

\section{- Marriage Status}

Marriage status in questionnaires has been arranged as three categories that are single, married, and divorced. This is a good question to know the female senior managers' family status. It also can reflect whether the successful female leaders have a great effect on their family and whether women leaders' marriage status is in a normal range. The following descriptive analysis will show the distribution of marriage status for female leaders. 
Table 11. Descriptive analysis of marriage status

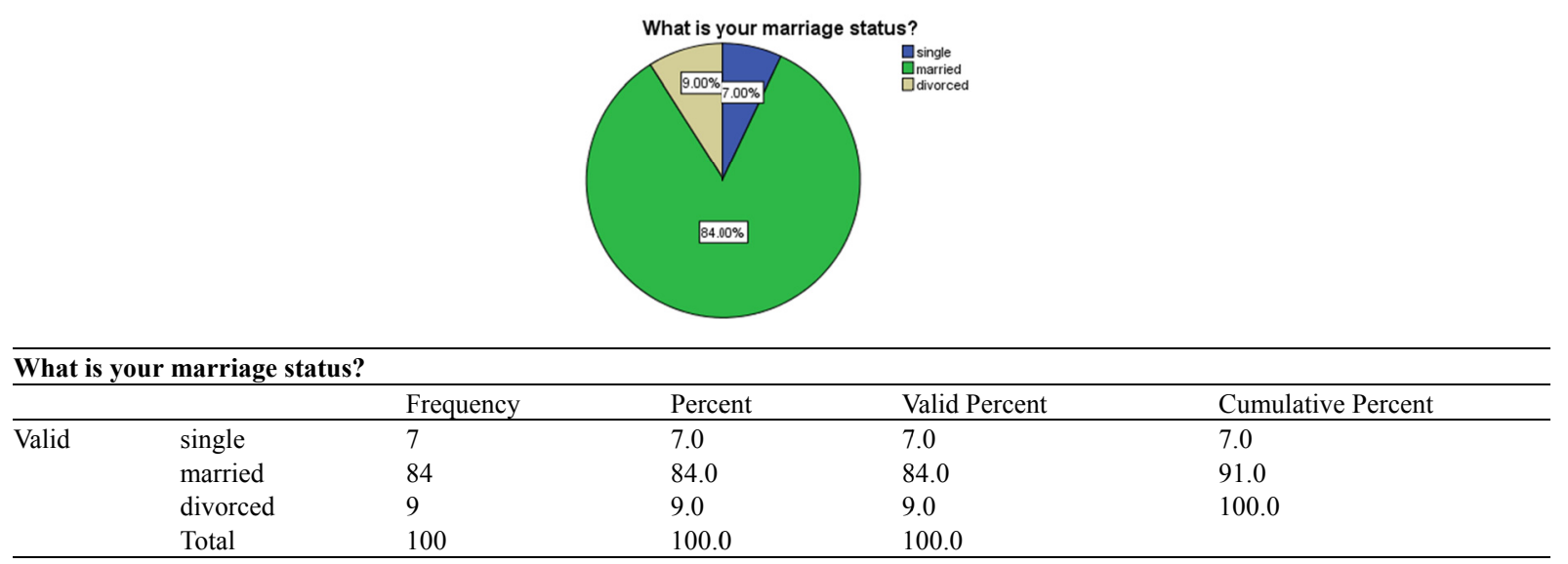

From the table above, it is clear to see that most of the female senior managers are married, and there are 84 married women out of the respondents ( $84 \%$ of all the respondents). On the other side, there are only $7 \%$ ( $7 \%$ of all the respondents) single respondents and $9 \%$ ( $9 \%$ of all the respondents) divorced respondents in this research. Most of female senior managers have a lovely family, and this is the premise for their career prospect.

\section{- Education Level}

This is a question to know the education level among respondents. It is necessary to classify education level for female senior managers in order to see whether it will affect women leadership. Education level has been arranged as four categories that are under degree Level, degree, master's degree, and $\mathrm{PhD}$. The descriptive analysis of education level mainly indicates the distribution of women leaders in education.

Table 12. Descriptive analysis of education level

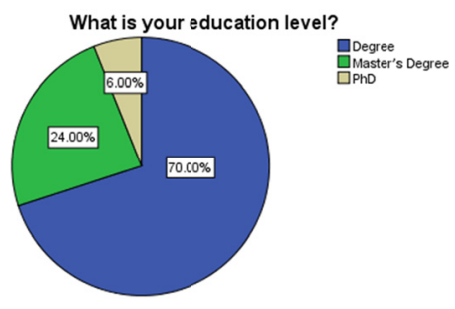

\begin{tabular}{llllll}
\hline What is your education level? & & & & \\
& & Frequency & Percent & Valid Percent & Cumulative Percent \\
\hline Valid & Degree & 70 & 70.0 & 70.0 & 70.0 \\
& Master's Degree & 24 & 24.0 & 24.0 & 94.0 \\
& PhD & 6 & 6.0 & 100.0 \\
& Total & 100 & 100.0 & 100.0 & \\
\hline
\end{tabular}

From the table above, it obviously shows that there is no respondent under degree level which indicates that female senior managers usually have a well-developed academic background in Kuala Lumpur. Most of respondents are in degree education level, and it has a high percentage of respondents that is $70 \%$ ( 70 respondents out of 100 respondents). There are 24 women (24\% of all the respondents) in the level of master's degree and 6 women ( $6 \%$ of all the respondents) in the level of $\mathrm{PhD}$ in this questionnaire that totally occupy $30 \%$ of all respondents. The different education levels reflect the main educational distribution in women leadership; it will be easier to know why female leaders also can be qualified for the leaders work.

\section{- Working Experience}

This is a question to know how long female senior managers have held a managerial position in corporation. The result can indicate the promoted period for women leaders from a normal worker to a manager. It is very necessary to classify working experience for female senior managers in order to see whether it will affect women leadership. Female senior managers' working experience has been arranged as three categories that are 3-5 years, 
6-10 years, and above 10 years.

Table 13. Descriptive analysis of working experience

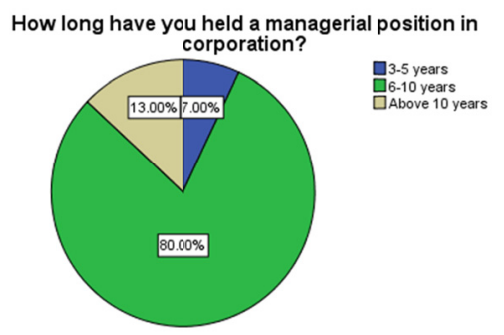

\begin{tabular}{|c|c|c|c|c|c|}
\hline \multicolumn{6}{|c|}{ How long have you held a managerial position in corporation? } \\
\hline & & Frequency & Percent & Valid Percent & Cumulative Percen \\
\hline \multirow[t]{4}{*}{ Valid } & $3-5$ years & 7 & 7.0 & 7.0 & 7.0 \\
\hline & $6-10$ years & 80 & 80.0 & 80.0 & 87.0 \\
\hline & Above 10 years & 13 & 13.0 & 13.0 & 100.0 \\
\hline & Total & 100 & 100.0 & 100.0 & \\
\hline
\end{tabular}

The above table shows the distribution of different ranges of female senior managers' working experience from different SMEs in Kuala Lumpur. The range of "above 10 years" takes $13 \%$ (13 out of 100 respondents) of all the respondents. Most female leaders' working experience belongs to the range of " $6-10$ years", which takes $80 \%$ ( 80 out of 100 respondents) of all the respondents. While, there are only $7 \%$ ( 7 out of 100 respondents) female becoming managers in a short time, who are in the range of "3-5 years".

\section{- Enterprise}

Enterprise in questionnaires has been distributed to five categories of industries that are bank, cosmetic/healthcare service industry, hotel, insurance company, and retail group. This a necessary question to see the distribution of target respondents, the wide distribution of respondents is order to get an exact and objective result from the questionnaires. The following descriptive analysis will show the distribution of enterprise in which female senior manager work.

Table 14. Descriptive analysis of enterprise

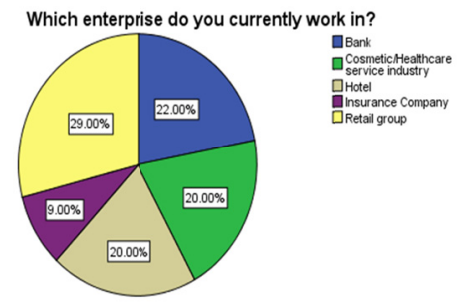

\begin{tabular}{|c|c|c|c|c|c|}
\hline \multicolumn{6}{|c|}{ Which enterprise do you currently work in? } \\
\hline & & Frequency & Percent & Valid Percent & Cumulative Percent \\
\hline \multirow[t]{6}{*}{ Valid } & Bank & 22 & 22.0 & 22.0 & 22.0 \\
\hline & Cosmetic/Healthcare service industry & 20 & 20.0 & 20.0 & 42.0 \\
\hline & Hotel & 20 & 20.0 & 20.0 & 62.0 \\
\hline & Insurance Company & 9 & 9.0 & 9.0 & 71.0 \\
\hline & Retail group & 29 & 29.0 & 29.0 & 100.0 \\
\hline & Total & 100 & 100.0 & 100.0 & \\
\hline
\end{tabular}

From the table above, female senior managers from bank take $22 \%$ (20 respondents out of 100 respondents) of all respondents. There are 20 female leaders $(20 \%)$ from cosmetic/healthcare service industry, while the percentage of respondent is $29 \%$ ( 29 respondents out of 100 respondents) who are from retail group. In hotel industry, it takes $20 \%$ (20 respondents out of 100 respondents) of all respondents. The smallest group is from insurance company, which only takes $9 \%$ ( 9 respondents out of 100 respondents) of all respondents. 


\section{- Four Dimensions}

The four factors were calculated respectively in order to find out the mean and standard deviation. The following descriptive table shows the means; standard deviations and missing value of each factor.

Table 15. Descriptive analysis of difference on glass ceiling effect

\begin{tabular}{|c|c|c|c|c|c|}
\hline \multicolumn{6}{|c|}{ Statistics } \\
\hline & & \multicolumn{4}{|c|}{$\begin{array}{l}\text { Do you think male staff } \\
\text { has much more chancesDo you think women areDo you think gender isceiling effect will have a } \\
\text { and faster speed formore difficult to developthe barrier to promotionnegative influence on } \\
\text { promotion? }\end{array}$} \\
\hline \multirow[t]{2}{*}{$\mathrm{N}$} & Valid & 100 & 100 & 100 & 100 \\
\hline & Missing & 0 & 0 & 0 & 0 \\
\hline \multicolumn{2}{|c|}{ Mean } & 3.11 & 3.11 & 3.15 & 3.29 \\
\hline \multicolumn{2}{|c|}{ Std. Deviation } & .510 & .510 & 609 & .608 \\
\hline \multicolumn{2}{|c|}{ Minimum } & 2 & 2 & 2 & 2 \\
\hline \multicolumn{2}{|c|}{ Maximum } & 4 & 4 & 5 & 5 \\
\hline \multicolumn{2}{|c|}{ Sum } & 311 & 311 & 315 & 329 \\
\hline
\end{tabular}

Table 16. Descriptive analysis of difference on job satisfaction

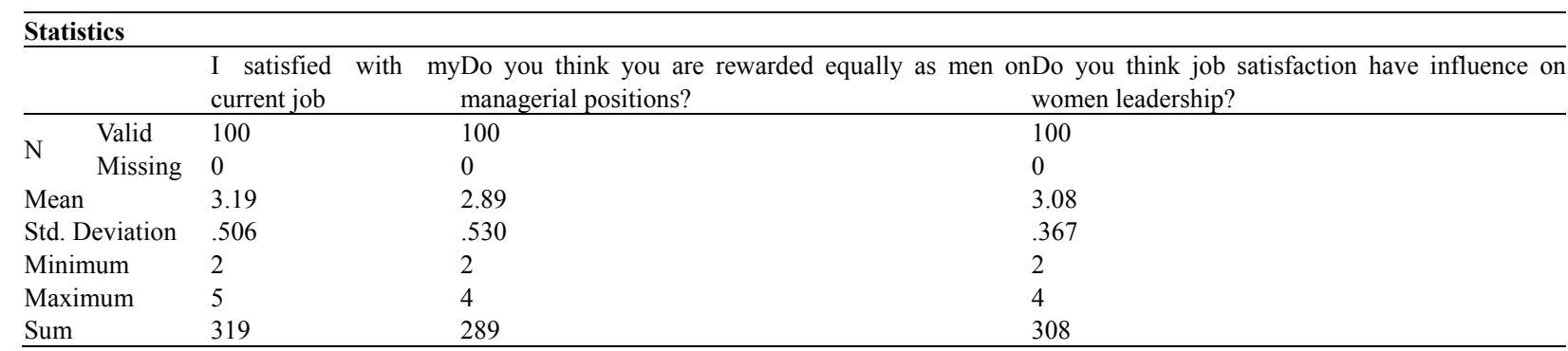

Table 17. Descriptive analysis of difference on moral character

\begin{tabular}{|c|c|c|c|c|c|}
\hline \multirow[t]{2}{*}{ Statistics } & \multirow{2}{*}{\multicolumn{2}{|c|}{$\begin{array}{l}\text { I have a strongI have a strong sense } \\
\text { sense of groupresponsibility and I } \\
\text { honour? } \\
\text { everything seriously at work }\end{array}$}} & \multirow{2}{*}{\multicolumn{3}{|c|}{$\begin{array}{l}\text { ofI can be very patient toFor the issue of work, II think moral character will be } \\
\text { dolisten and acceptalways prior to benefitthe most influential factor for } \\
\text { different opinions company }\end{array}$}} \\
\hline & & & & & \\
\hline N Valid & 100 & 100 & 100 & 100 & 100 \\
\hline Missing & 0 & 0 & 0 & 0 & 0 \\
\hline Mean & 3.34 & 3.32 & 3.39 & 3.45 & 3.44 \\
\hline $\begin{array}{l}\text { Std. } \\
\text { Deviation }\end{array}$ & .555 & .548 & .584 & .626 & .656 \\
\hline Minimum & 2 & 2 & 2 & 3 & 2 \\
\hline Maximum & 5 & 5 & 5 & 5 & 5 \\
\hline Sum & 334 & 332 & 339 & 345 & 344 \\
\hline
\end{tabular}

Table 18. Descriptive analysis of difference on organisational citizenship behaviour

\begin{tabular}{|c|c|c|c|c|c|}
\hline \multicolumn{6}{|l|}{ Statistics } \\
\hline & \multicolumn{5}{|c|}{$\begin{array}{l}\mathrm{I} \text { am willing to offerI will take the initiative toI will never useI think organizational } \\
\text { I am willing to helpadvice and suggestions tohelp company pullcompany resources andcitizenship behaviour is an } \\
\text { subordinates to solveimprove the status of thethrough when companymy position to gainimportant factor affecting } \\
\text { problems at work company }\end{array}$} \\
\hline N Valid & 100 & 100 & 100 & 100 & 100 \\
\hline Missing & 0 & 0 & 0 & 0 & 0 \\
\hline Mean & 3.33 & 3.31 & 3.29 & 3.50 & 3.43 \\
\hline Std. & .551 & .598 & .556 & .704 & .728 \\
\hline \multicolumn{6}{|c|}{ Deviation } \\
\hline Minimum & 2 & 2 & 2 & 3 & 2 \\
\hline Maximum & 5 & 5 & 5 & 5 & 5 \\
\hline
\end{tabular}




\begin{tabular}{|c|c|c|c|c|c|}
\hline \multicolumn{6}{|l|}{ Statistics } \\
\hline & \multicolumn{5}{|c|}{$\begin{array}{l}\text { I am willing to offerI will take the initiative toI will never use I think organizational } \\
\text { padvice and suggestions tohelp company pullcompany resources andcitizenship behaviour is an } \\
\text { eimprove the status of thethrough when companymy position to gainimportant factor affecting } \\
\text { company } \\
\text { get into difficulty } \quad \text { personal benefit } \\
\text { women leadership }\end{array}$} \\
\hline NValid & 100 & 100 & 100 & 100 & 100 \\
\hline Missing & 0 & 0 & 0 & 0 & 0 \\
\hline Mean & 3.33 & 3.31 & 3.29 & 3.50 & 3.43 \\
\hline Std. & .551 & .598 & .556 & .704 & .728 \\
\hline \multicolumn{6}{|c|}{ Deviation } \\
\hline Minimum & & 2 & 2 & 3 & 2 \\
\hline Maximum & & 5 & 5 & 5 & 5 \\
\hline Sum & 333 & 331 & 329 & 350 & 343 \\
\hline
\end{tabular}

For the descriptive table of four variables, it is clear to see that there are no any missing values for each variable; it is mainly because of the artificial avoidance in the process of questionnaire distribution. According to the graph above, it indicates the means, standard deviation, minimum and maximum values for every question in each variable. It is clear to see that most of the questions have no big difference between maximum and minimum values. On the other hand, the standard deviation for most questions is relatively low, which indicates the data are spread out over a small range of values. As a result, the tables of descriptive analysis show that the opinions of respondents have no big difference for these variables.

\subsection{Hypothesis Testing of Relationship}

\subsubsection{Chi-Square Analysis}

In the section above, Chi-square is a statistical test the existence of a relationship between categorical independent variables on a categorical dependent variable (Joyce, 2002). The $95 \%$ level of confidence will be used to make sure the degree of relationship between two variables; thus, it will leave $5 \%(\alpha=0.05)$ for the rejection and risk.

\section{- Four Dimensions and Women Leadership}

Based on the research objective, chi-square analysis test is whether there is statistically significant relationship between the four variables (glass ceiling effect, job satisfaction, moral character, organisational citizenship behaviour) and women leadership in senior management level in SMEs, and to identify the influence and effectiveness of each factor.

Table 19. Summary description of Chi-Square test

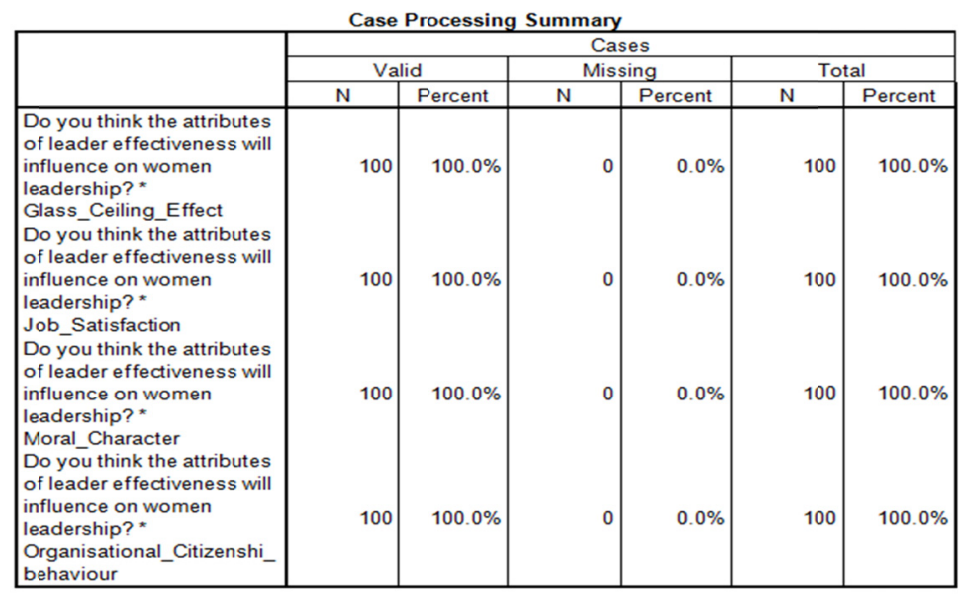

The above table indicates that the valid data are $100 \%$, and missing data is 0 ; it means there is no any missing value for each variable and all results are Validity. The following part will introduce four hypothesis tests:

\section{$>\quad H y p o t h e s i s$ of glass ceiling effect and women leadership in senior management level}

$\mathrm{H}_{0}$ : there is no relationship between glass ceiling effect \& women leadership.

$\mathrm{H}_{1}$ : there is a significant relationship between glass ceiling effect \& women leadership. 
Table 20. Chi-Square test of glass ceiling effect and women leadership

Chi-Square Tests
\begin{tabular}{|l|r|r|r|}
\hline & \multicolumn{1}{|c|}{ Value } & \multicolumn{1}{c|}{ df } & \multicolumn{1}{c|}{$\begin{array}{c}\text { Ssymp. Sig. (2- } \\
\text { sided) }\end{array}$} \\
\hline Pearson Chi-Square & $22.549^{9}$ & 8 & .004 \\
Likelihood Ratio & 9.859 & 8 & .275 \\
Linear-by-Linear & .082 & 1 & .775 \\
Association & 100 & & \\
N of Valid Cases & & \\
\hline
\end{tabular}

The level of significance for chi-square test is 0.05 . From the table above, it is clear to see that the chi-square test is 0.004 ( $\rho$-value $=0.004)$. As a result, $\rho$-value is less than $0.05(\rho$-value $=0.004<0.05)$, the statistic is considered to be significant, which means researcher can be $95 \%$ confident for the relationship between two attributes not due to chance. Therefore, $\mathrm{H}_{0}$ will be rejected, it can accepts the alternative hypothesis $\left(\mathrm{H}_{1}\right)$ at the alpha level of 0.05 , the result can be concluded that glass ceiling effect and women leadership are dependent or existing strong relationship.

\section{Hypothesis of job satisfaction and women leadership}

$\mathrm{H}_{0}$ : there is no relationship between job satisfaction and women leadership.

$\mathrm{H}_{1}$ : there is a significant relationship between job satisfaction and women leadership.

Table 21. Chi-Square test of job satisfaction and women leadership

\begin{tabular}{|c|c|c|c|}
\hline & Value & df & $\begin{array}{c}\text { Asymp. Sig. (2- } \\
\text { sided) }\end{array}$ \\
\hline $\begin{array}{l}\text { Pearson Chi-Square } \\
\text { Likelihood Ratio } \\
\text { Linear-by-Linear } \\
\text { Association } \\
\mathrm{N} \text { of Valid Cases }\end{array}$ & $\begin{array}{r}2.462^{\mathrm{g}} \\
3.433 \\
.027 \\
100\end{array}$ & \begin{tabular}{r|}
11 \\
11 \\
1
\end{tabular} & $\begin{array}{r}.996 \\
.984 \\
.868\end{array}$ \\
\hline
\end{tabular}

Based on the table above, the Sig. value is 0.996 , therefore, the $\rho$-value is greater than $0.05(0.996>0.05)$, the statistic is considered to be not significant. $\mathrm{H}_{0}$ should not be rejected, it can be concluded that job satisfaction and women leadership are independent at 0.05 of confidence level.

\section{Hypothesis of moral character and women leadership}

$\mathrm{H}_{0}$ : there is no relationship between moral character and women leadership.

$\mathrm{H}_{1}$ : there is a significant relationship between moral character and women leadership.

Table 22. Chi-Square test of moral character and women leadership

\begin{tabular}{|l|r|r|r|}
\hline & \multicolumn{1}{|c|}{ Chi-Square Tests } \\
\hline & & df & $\begin{array}{c}\text { Asymp. Sig. (2- } \\
\text { sided) }\end{array}$ \\
\hline Pearson Chi-Square & $35.673^{3}$ & 11 & .000 \\
Likelihood Ratio & 21.851 & 11 & .026 \\
Linear-by-Linear & .211 & 1 & .646 \\
Association & 100 & & \\
N of Valid Cases & &
\end{tabular}

From the table above, it is clear to see that the significance of chi-square test is 0.000 ( $\rho$-value $=0.000$ ) at 0.05 of confidence level. Because the $\rho$-value is less than $0.05\left((\rho\right.$-value $=0.000<0.05), H_{0}$ will be rejected. Therefore, the Alternative hypothesis $\left(\mathrm{H}_{1}\right)$ can be accepted at 0.05 of confidence level, the result indicates that there is a significant relationship between moral character and women leadership. 


\section{Hypothesis of organisational citizenship behaviour and women leadership}

$\mathrm{H}_{0}$ : there is no relationship between organisational citizenship behaviour and women leadership.

$\mathrm{H}_{1}$ : there is a significant relationship between organisational citizenship behaviour and women leadership.

Table 23. Chi-Square test of organisational citizenship behaviour and women leadership

Chi-Square Tests

\begin{tabular}{|l|r|r|r|}
\hline & \multicolumn{1}{|c|}{ Value } & \multicolumn{1}{c|}{ df } & \multicolumn{1}{|c|}{$\begin{array}{c}\text { Asymp. Sig. (2- } \\
\text { sided) }\end{array}$} \\
\hline Pearson Chi-Square & $59.888^{9}$ & 9 & .000 \\
Likelihood Ratio & 22.999 & 9 & .006 \\
Linear-by-Linear & 12.359 & & 1 \\
Association & 100 & & .000 \\
N of Valid Cases & & \\
\hline
\end{tabular}

From the table above, it is clear to see that the significance of chi-square test is 0.000 ( $\rho$-value $=0.000$ ) at 0.05 of confidence level. Because the $\rho$-value is less than 0.05 ( $(\rho$-value $=0.000<0.05), \mathrm{H}_{0}$ will be rejected. Therefore, the Alternative hypothesis $\left(\mathrm{H}_{1}\right)$ can be accepted at 0.05 of confidence level, the result indicates that there is a significant relationship between organisational citizenship behaviour and women leadership.

5.3.2 Correlation coefficients analysis

Correlation coefficient is a measure of association between two normally distributed interval variables (independent variables). For this analysis, it will use the $99 \%$ level of confidence in order to make sure the degree of relationship between two independent variables. The most frequent value is $99 \%$ level of confidence (Sekaran and Bougie, 2009), it will use in this research. The value of correlation coefficient (commonly known as $r$ value) ranges between -1 and +1 . The following figure will show the strength relationship of correlation coefficient.

\section{Correlation Coefficient \\ Shows Strength \& Direction of Correlation}

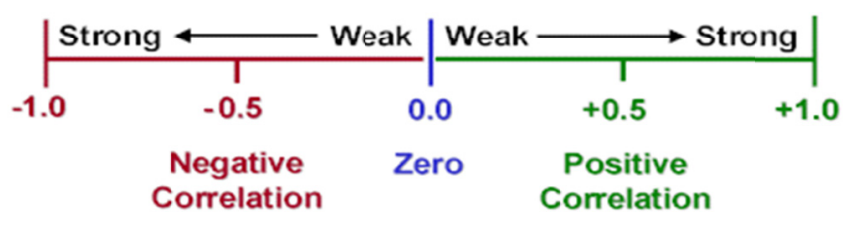

Figure 1. The Strength Relationship of correlation coefficient

Source: Adopted from wordpress.com (2012).

This part will clearly show the strong or weak relationship between two independent variables. The following table will show the range of correlation coefficient. 
Table 24. Interpretation of the value for $\mathrm{R}$

\begin{tabular}{|c|l|}
\hline The Range of $\mathrm{r}$ & \multicolumn{1}{|c|}{ Interpretation } \\
\hline $\mathrm{r}=-1$ & Perfect negative correlation \\
\hline$-1<\mathrm{r} \leq-0.8$ & Strong negative correlation \\
\hline$-0.8<\mathrm{r} \leq-0.5$ & Fair negative correlation \\
\hline$-0.5<\mathrm{r}<0$ & Weak negative correlation \\
\hline $\mathrm{r}=0$ & No correlation \\
\hline $0<\mathrm{r}<0.5$ & Weak positive correlation \\
\hline $0.5 \leq \mathrm{r}<0.8$ & Fair positive correlation \\
\hline $0.8 \leq \mathrm{r}<1$ & Strong positive correlation \\
\hline $\mathrm{r}=1$ & Perfect positive correlation \\
\hline
\end{tabular}

\section{Hypothesis}

$\mathrm{H}_{0}$ : There is no correlation relationship between any two attributes.

$\mathrm{H}_{1}$ : There is a correlation relationship between any two attributes.

Table 25. Correlation analysis for four independent variables

\begin{tabular}{|c|c|c|c|c|c|}
\hline \multicolumn{6}{|c|}{ Correlations } \\
\hline & & $\begin{array}{c}\text { Glass_Ceiling } \\
\text { _Effect }\end{array}$ & $\begin{array}{c}\text { Job_Satisfacti } \\
\text { on }\end{array}$ & $\begin{array}{l}\text { Moral_Charac } \\
\text { ter }\end{array}$ & $\begin{array}{c}\text { Citizenship_b } \\
\text { ehaviour }\end{array}$ \\
\hline \multirow[t]{3}{*}{ Glass_Ceiling_Effect } & Pearson Correlation & 1 & .002 & -.139 & -.166 \\
\hline & Sig. (2-tailed) & & .985 & .168 & .098 \\
\hline & $\mathrm{N}$ & 100 & 100 & 100 & 100 \\
\hline \multirow{3}{*}{ Job_Satisfaction } & Pearson Correlation & .002 & 1 & .085 & $.200^{\circ}$ \\
\hline & Sig. (2-tailed) & .985 & & .401 & .046 \\
\hline & $\mathrm{N}$ & 100 & 100 & 100 & 100 \\
\hline \multirow[t]{3}{*}{ Moral_Character } & Pearson Correlation & -.139 & .085 & 1 & $.360^{\circ}$ \\
\hline & Sig. (2-tailed) & .168 & .401 & & .000 \\
\hline & $\mathrm{N}$ & 100 & 100 & 100 & 100 \\
\hline \multirow[t]{3}{*}{ Citizenship_behaviour } & Pearson Correlation & -.166 & $.200^{\circ}$ & $.360^{\circ}$ & 1 \\
\hline & Sig. (2-tailed) & .098 & 046 & .000 & \\
\hline & $\mathrm{N}$ & 100 & 100 & 100 & 100 \\
\hline
\end{tabular}

From the table above, it reflects the result between one variable and other three variables. According to the outputs, $\rho$-value of moral character is 0.000 relate to organisational citizenship behaviour, which is less than $0.01(\rho$-value $=0.000<0.01)$. Thus, the null hypothesis $\left(\mathrm{H}_{0}\right)$ will be rejected, which means there is a correlation relationship between moral character and organisational citizenship behaviour. Furthermore, the Pearson Correlations is in the range between 0 and +0.5 that is 0.360 , As a result, there is a weak positive linear correlation relationship between moral character and organisational citizenship behaviour.

On the other hand, the Sig. score of glass ceiling effect is 0.985 related to job satisfaction, which $\rho$-value is more than 0.01 ( $\rho$-value $0.985>0.01$ ), therefore, the null hypothesis $\left(\mathrm{H}_{0}\right)$ will be accepted, which means there is no correlation relationship between glass ceiling effect and job satisfaction. By this way, $\rho$-value of glass ceiling effect relates to moral character is $0.168>0.01$ and relates to organisational citizenship behaviour is $0.098>0.01$, thus, glass ceiling effect has no correlation relationship with moral character and organisational citizenship behaviour. Besides this, from the table above, the result also indicates that the Sig. score of job satisfaction is 0.401 ( $\rho$-value $0.401>0.01$ ) related to moral character, and $\rho$-value of job satisfaction relates to organisational citizenship behaviour is $0.046>0.01$. Therefore, the null hypothesis $\left(\mathrm{H}_{0}\right)$ will be accepted, which means there are no correlation relationships between each other. Thus, job satisfaction has no correlation relationship with moral character as well as job satisfaction has no correlation relationship with organisational citizenship behaviour.

\subsection{Ranking the Most Significant Factors on Women Leadership}

This question is order to find out the most important factors on women leadership and the answers is by the women leaders' prospective to rank the four variables based on the degree of the important. The following figure shows the frequency of selected "the most important" of all. 
Table 26. Most influential factor on women leadership

\begin{tabular}{|c|c|c|c|c|c|}
\hline \\
\hline & & Frequency & Percent & Valid Percent & $\begin{array}{c}\text { Cumulative } \\
\text { Percent }\end{array}$ \\
\hline \multirow[t]{5}{*}{ Valid } & Glass ceiling effect & 20 & 20.0 & 20.0 & 20.0 \\
\hline & Job satisfaction & 6 & 6.0 & 6.0 & 26.0 \\
\hline & Moral character & 39 & 39.0 & 39.0 & 65.0 \\
\hline & $\begin{array}{l}\begin{array}{l}\text { organis ational citizenship } \\
\text { behaviour }\end{array} \\
\text { int }\end{array}$ & 35 & 35.0 & 35.0 & 100.0 \\
\hline & Total & 100 & 100.0 & 100.0 & \\
\hline
\end{tabular}

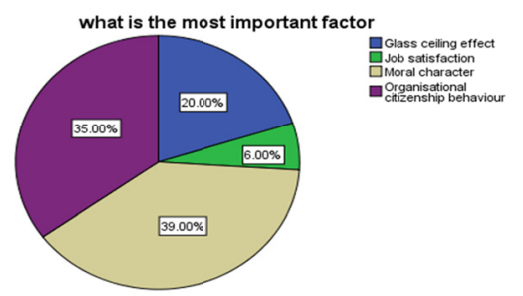

Each variable for the related factors on women leadership has ranked from the most important to the least important (from 1 to 4). From the figure above, it is clear to see that there are $39 \%$ of the respondents who rank "Moral Character" as the most important factor, which means they considered moral character as the most important factor that influence women leadership. After that, it is "Organizational Citizenship Behaviour" (35\%), "Glass Ceiling Effect" (20\%), and "Job Satisfaction" (6\%).

\section{Findings and Recommendation}

Combined with the above results of data analysis, this chapter summarizes the hypotheses verification results, draw the findings and conclusions of the study, to propose appropriate management recommendations for the conclusion.

\subsection{Findings}

Based on the variety of statistical analysis in chapter 4 , the hypothesis test results are related to the research objectives and problems statement. In research, the writer study on the basic relationship between women's leadership and the influential factors of women's leadership through questionnaire survey. The research has conducted among several SMEs in Kuala Lumpur; it has studied the dimensions of leadership effectiveness and influential factors of women's leadership in Malaysian enterprises, discussed the relationship between women's leadership and the influential factors of women's leadership as well. In this chapter, the writer will conduct further discussions to some of the problems in the empirical analysis, in order to better understand women leadership in Malaysia.

\subsection{Target Market Segmentation}

Target Market refers to the geographic market which can help to divide the market into small units comprising people with similar purpose (Kelley \& Jugenheimer, 2008). Target market can be divided into market segments and can be used to define a demographic target. In this study, female senior managers from nine SMEs in Kuala Lumpur are the target market. The following part will summarize the results of target market for this project.

Table 27. Target market segmentation

Segmentation Description
variables

\begin{tabular}{|c|c|c|}
\hline Demographic & Age & $\begin{array}{l}\text { According to the descriptive analysis, it shows that the group of } 40-49 \text { year-old" occupies most } \\
\text { volume of the frequency, which is } 54 \% \text { of } 100 \text { respondents. There are } 40 \% \text { of female senior managers } \\
\text { in the range of " } 30-39 \text { years old", while the percentage of respondent is only } 4 \% \text { who above } 50 \text { years } \\
\text { old and only } 2 \% \text { who range up to } 30 \text { years old. The respondents are more come from } 40 \text { to } 49 \text { years } \\
\text { old of age group, which means middle age female managers occupy a high percentage of the total } \\
\text { female senior managers in enterprises. }\end{array}$ \\
\hline
\end{tabular}

Marriage status The results indicate that most female leaders have a stable and happy family. In the total 100 respondents, there are $84 \%$ female senior managers are married, only $9 \%$ of them are divorced and $7 \%$ of them are still remaining single. A high percentage of Malaysia female senior leaders have been 
married and have a stable and happy family and life.

Education level In the 100 questionnaires, it obviously shows that there is no respondent under degree level, which indicates that female senior managers usually have a well-developed academic background in Kuala Lumpur. There are $70 \%$ of all the respondents are under the bachelor's degree. $24 \%$ of them are in the level of master's degree. Besides, there are $6 \%$ of female leaders have gotten PhD. The result shows that the academic backgrounds of female leaders are improved. Most female senior managers in Malaysia have considerable knowledge and qualifications compare to the past.

Years of According to the descriptive analysis, it shows that most of the respondents are held senior managerial holding position within 6-10 years, and it has a high percentage of respondents that is $80 \%$. There are $13 \%$ of managerial female leaders have more than 10 years working experience, and only $7 \%$ of female leaders held position senior managerial position within 3-5 years. The different year of work experience can reflect that it will take a long time for women becoming senior managers. The promotion for women in enterprises still exist difficulties and obstacles in Malaysia.

Type of In this question, the results indicate that female leaders are more existed in consumer service enterprise companies. $29 \%$ of all respondents are from retail group. Female senior managers from bank take $22 \%$ of all respondents. There are $20 \%$ of female leaders from cosmetic/healthcare service industry as well as $20 \%$ of female leaders from Hotel. There are $9 \%$ from insurance company which are the smallest group of all respondents. The analysis proved that female leaders are more suited in certain occupations such as: consumer service managers; accountants and financial managers; cosmetic and health services managers and social community service managers (Toegel, 2010).

Geographic Female senior managers in SMEs are the target female leaders in this study. Those nine SMEs in Kuala Lumpur are including Hong Leong Bank; Kuwait Finance House Berhad; Poney Company; PepsiCo; Shahnaz Herbals; Slimming Sanctuary Sdn Bhd; Royale Chulan Hotel; Sunway Retail Group and Malaysian Insurance Institute. According to preview study, those nine are the typical small and medium enterprises which have most female leaders compared to other SMEs in Kuala Lumpur, and those can represent the majority of women leadership in Malaysia.

From the analysis of target market segmentation, those female senior managers are mainly distributed between 40-49 years old, which the age of having a stable family, children begin to be independent. The burden on family has been lightened, thus they have the energy and time to organize the work and stretches their ability. Women employees in this age also accumulated several years of work experience and management capabilities. Therefore, the majority of senior women leaders are distributed at this stage, and this stage also can better reflect the superiority of women's leadership.

\subsection{Four Variables}

In order to determine the further relationship between the independent variables and the dependent variables, Chi-square tests are introduced to the hypothesis test. There are differences between each factor towards to women's leadership. From the results, except job satisfaction, other three dimensions of leadership effectiveness have significant influence on women's leadership. In other word, the effectiveness of women's leadership will present significant difference along different dimensions.

Glass ceiling effect has an influence on women's leadership. The attitude of cultural and social thought that there are occupational segregation between male and female in workplace. Most women in senior management positions have met the glass ceiling to career advancement now or before. Major respondents felt barriers still existed for women's advancement and unfair competition environment among organisations. Therefore, compared to male leaders, female leaders are considered more difficult and stressful at work. On the other hand, job satisfaction are identified has no influence on women's leadership. For example, glass ceiling effect will always exist whether women satisfied their work or not. There is no relationship or logically connection between job satisfaction and women's leadership. As long as women in the management positions, they will insist their moral standard regardless of satisfaction with job.

Moral characters and organisational citizenship behaviour have positive and significant influence on women's leadership. Based on the analysis of hypothesis test, majority female senior managers show strong moral standard and organisational citizenship behaviour at work. This study provides further evidence that moral characters and organisational citizenship behaviour does have a positive influence on women's leadership. For example, strong moral standard and organisational citizenship behaviour will bring an effective women leadership, while worse moral standard and organisational citizenship behaviour will lead an inefficient women 
leadership.

Moral character is the basic foundation of improving leadership authority. The influence of the leader's character, personality and style will also infect and guide the subordinates. The influence of leader's character factors will be different. If the leader with high moral character, subordinates will be more trust, dependency and reverence, and those feeling will transform into the conscious action and strength, enabling them to make unremitting efforts to struggle in order to achieve work goals. The finding implicates that companies may want to hire or promote people who has similar moral and values to the companies; skills can be taught, but core beliefs and values may not (Vondey, 2010). Instead of focusing on the qualified skills for a job, organisation should focus more on how well the moral character and organisational citizenship behaviour the leaders fits with.

From the analysis of research on women's leadership, when women leaders' glass ceiling feelings are weak, there will be high effectiveness of women leadership; when women leaders have great moral characters and good organisational citizenship behaviour, the leadership effectiveness of women will be high. Female leaders with low glass ceiling effect will more motive their career advancement. In conclusion, the results are consistent with previous research on literature review, and the influenced factors for women leadership which have been identified can refer to objectives of study.

In order to determine the relationship among independent variables, it can be referred to correlation analysis. The correlation analysis indicates that that there is a weak correlation relationship between moral character and organisational citizenship behaviour. For the others results of correlation, there are no relationships between others independent variables each other. In small medium enterprises, moral character shows positive relevance with organisational citizenship behaviour compared with job satisfaction of female senior managers. Female senior managers with more outstanding moral character will bring relative better organisational citizenship behaviour. In Malaysia's small medium enterprises, the personality traits of good senior managers are honestly, integrity, fairness and loyalty. Rather than only considered the wellbeing of themselves, those with good moral character are willing to helping others and providing benefits to public which are coincident with some common traits of organisational citizenship behaviour. The common traits in organizational citizenship behaviour include maintain friendship with employees and keeps the spirits, active involvement in social company activities and have common value to the rules and culture of company. Good female senior managers who practices organisational citizenship behaviour will typically become a strong team player in order to benefit to the company.

\subsubsection{The Most Influential Factor}

This part is going to find out female leaders' perception in the study of women leadership. The following part will descript the frequency for different ranking which the respondents were asked to rank the four variables from most important to least important. The table bellows shows the frequency of this question:

Table 28. Result of ranking the most influential factor of women leadership

\begin{tabular}{lll}
\hline Influential factors & Most influential factor & Percentage \\
\hline Glass Ceiling Effect & 20 & $20 \%$ \\
Job Satisfaction & 6 & $6 \%$ \\
Moral Character & 39 & $39 \%$ \\
Organizational Citizenship Behaviour & 35 & $35 \%$ \\
\hline
\end{tabular}

The result indicates that most female senior managers considered that moral character are the most important factor which can effectively affect women leadership as well. According to Grace, N (2012), moral character is the virtues and ethics of people. Especially in small-medium enterprises, good moral character is essential for employee particularly for those in management positions, leaders with good moral character in the workplace can bring growth of the company. From the analysis, it has identified that women are too moral to succeed in business (Kaputa, 2009). A number of women considered that moral are the inevitable factor for a successful leadership in work.

\subsection{Summaries of Finding}

There has been significant difference between women leaders from different age, education level, years of managerial experience and types of enterprises. Different demographic background of women leaders will cause different influence degree to women's leadership. Glass ceiling effect, job satisfaction, moral characters and organisational citizenship behaviour are the four important dimensions of leadership effectiveness. The 
effectiveness of leadership is the important indicators of women's leadership. Women leadership can be affected by glass ceiling effect, moral characters and organisational citizenship behaviour, among them moral characters are the main influential factor of women's leadership; glass ceiling effect and organisational citizenship behaviour still have significant influence on women's leadership, however, job satisfaction of women leaders have seldom relationship on women's leadership.

Recommendations

Based on the above findings, the writer has put forward the following suggestions and hope to be able to help the female business leaders for their management practices.

\subsection{Recommendation for Managerial Level}

This study has determined the existence of a glass ceiling. There are obstacles for women promotion in organizations. This is contrary to the goal of maximizing organization and social interests. In order to optimize the allocation of resources and make full use of the competency of staff, enterprises should try to break the glass ceiling as soon as possible; pave the way for female employees and avoid gender stereotypes that may caused loss to enterprises.

1) To promote the appropriate proportion of female managers and a higher proportion of female executives. This study provides the basis for the proportion of men and women in management. An appropriately increase the proportion of female in management and the senior management team, will help to break down the "glass ceiling effect" in order to fully use women's human resources. Besides, the senior management team of gender diversity will benefit organisational citizenship behaviours. Therefore, enterprises should ensure gender balance in management and a higher proportion of female executives as far as possible.

2) Bring the gender awareness into the company's strategic development decision. It is necessary for managerial level to consider the different physiological conditions and psychological characteristics between men and women; consider the different type of family responsibilities and conceptions; give special attention and dedicated support for women in the company, and those will help to achieve a win-win strategy for the development of women and enterprises.

3) To create a company culture that is conducive to women's development. In company, management level should publicize examples of outstanding female entrepreneurs, spread the spirit of those women, and encourage innovation, competition, and hard work, in order to promote the success and development of women's leadership.

\subsection{Recommendation for Women Leaders}

Women leaders need constantly enhance their leadership from their own point of view. No matter from the theory of leadership traits or leader competency model, based on Bilimoria and Piderit (2007), women leaders need develop or enhance leadership from the following aspects of culture:

1) Focus on the improvement of their quality, enhance leadership competency

The survey shows that there has been a big leap for women in leadership positions in the aspects of knowledge, qualifications compare to the past. Women leaders in this new era are urgent to improve their overall quality. In terms of skills, knowledge, physical fitness, professional ethics, cultural accomplishment, psychological quality, women leaders must continue to learn and grow. Women leaders need to have more unique qualities such as the indomitable will and a healthy attitude.

2) Use unique female advantage with flexible management to enhance leadership

Compared to Female leaders, male leaders have more potential for the implementation of flexible management. Due to women born relatively weak, women are rational and emotional. Compared to the leadership style of men, women leaders are more care about subordinates, more sensitive, and women are more inclined to adopt democratic leadership. Besides, women leaders more encourage participation, and willing to share power and information to subordinates. Furthermore, women are more compassionate and tolerant, willing to put ourselves in others' shoes. Female role of mother will make them full of unique love and patience, and has some credibility and representative power as well.

3) Identification of corporate value, encourage to break the irrational system

Share corporate values. If them find a system and corporate values do not match, they need to have the courage to break the irrational system. Many researchers also believe that women leaders lack of courage to challenge existing systems and policies. It is also reflects that women leaders need improve and upgrade their leadership. 


\subsection{Recommendation for Enterprise Level}

The enterprise is a unique environment for the survival and development of women leaders. Leadership situations is one of the three elements of leadership. Therefore, to create a good business environment is the first thing to enhance women's leadership. Only good and harmonious business environment can improve the conditions and basis of women leaders, and only by this, women will have the opportunity to be senior leader, and continue to enhance the leadership in the senior management position.

For the enterprise level, the most important is to design more equitable scientific measurement tools for the assessment of promotion, in order to ensure the enthusiasm and stability of the staff, and improve productivity and organizational performance; provide help and support to female employees and give full play to the abilities and strengths of each member of the organization, improve organizational effectiveness. According to Harzing and Pinnington (2011), there are four aspects for Enterprise Level:

\section{1) Establish a good employment selection mechanism}

Complete leadership talent selection mechanism is the first step for an enterprise to attract outstanding leadership talent. In the selection, enterprise should be regardless of gender, regardless of prejudice and discrimination against women and insist the "capable ability" fair selection mechanism. Enterprise should have equal treatment to women leaders and male leaders and this is the way of motiving women leaders. Besides, incentives will become a driving force to promote the advancement of women leaders. Therefore, with gratitude to enterprises, women leaders will do their best to benefit enterprise.

\section{2) Enhance the training of women leaders}

Enterprises should increase training opportunities in order to fundamentally upgrade skills of women leaders and promote their capabilities, which will lead to the enhancement of leadership of women leaders. What's more, pay attention to perfecting the talents training mechanism.

3) Build the corporate culture that is conducive to enhancing the women leadership

Corporate culture provides the orientation of business value. If employers and employees treat female leaders equitable and show welcoming attitude rather than exclusive attitude to female leaders, enterprises more pay attention to the abilities rather than gander in the employment selection, there will be further development for women leaders.

4) Establish a scientific and rational leadership measurement criteria and pay mechanism

Conduct evaluation to women's leadership; make a reasonable analysis to the evaluation results and timely feedback to the women leaders in order to maintain what has been achieved. Therefore, enterprises must develop standard with moderate and impartiality. Besides, enterprise requires women leader strict follow the standard, and uses certain standard to measure whether the standards suit for women leaders. In addition, a timely reminder and correction are required for women leaders to constantly improve their leadership and improve the standard when deviation happened in work.

\subsection{Recommendation for Social Environment Level}

Women embarked on the job of leader, engaged in senior-level leadership activities are considered inseparable with social progress, this is the sign of .social constant development and progression. The impact of the social context to a person is huge, the social awareness, customs and habits will be deep affect a person's growth. As mentioned by Connor, K (2010), there are three ways to promote women leadership from social environment level:

1) Society needs change concept, eliminate prejudice against women

Despite the increased proportion of women leaders in the contemporary era, due to affect by the traditional and backward old ethical and moral concepts, the inveteracy prejudices of female leaders are not eliminate, people still double about female leadership behaviour and female leadership skills. In real life, people still show more praise and encourage to male leaders with high-quality and pioneering spirit, social tend to provide them with more opportunities and resources. However, for the women who have a vision and risk-taking women, society often demand perfection and difficult to tolerance, they more tend to use the traditional "woman" standard to treat them.

\section{2) Pay attention to the personnel training of female leaders}

This will be first expressed in terms of social education. Social education is flexible and diversity, it can better reflect the democratic nature of education. The developed countries are equipped with all types of schools, 
subjects and courses from basic education, each year will provide society with a large number of management talents. Therefore, society could establish a variety of adult education schools, EMBA courses in order to help leader especially female leaders to continuously improve their leadership.

\section{3) Give favorable support to women leaders by their family}

If women more focus on career, she will less care family for sure. Women's emotional factors are higher than men. However it is difficult to balance between family and career. Family and career are indispensable for women leaders. Therefore, to enhance the leadership of women leaders, the primary thing is to make their family members understand and support them. Thus, when there come encountered problems or huge pressure, family members can share those problems and encourage, support them as well. Women leaders will have greater incentive to solve the problem and remove obstacle, finally they can make a difference in their leader position.

\section{Conclusion}

From the selection of subjects and completion the entire dissertation, from little understanding to deep understanding about the subject of women's leadership, the writer's perspective has become more rational and scientific. Based on consult a plenty of literature, the writer has learned the achievements of women's leadership by different scholars and learned the theory of leadership. Combined with own accumulated knowledge and used empirical analysis method, the writer eventually identified the influential factors of women's leadership and has completed the writing of the dissertation.

On the basis of literatures review, from an elaborate on women leadership theory; effectiveness of leadership and four dimensions of leadership effectiveness, these theoretical knowledge play a direct role to the analysis and conclusion to the study later. Combined with the actual situation of the female leaders in SMEs in Malaysia; through the survey analysis on female senior managers about the dimensions of leadership effectiveness in Malaysia SMEs, it can be concluded that leadership development for women in the great historical opportunity still exists obvious difficulties, and moral characters which as one dimension of leadership effectiveness are the most influential factor to women leadership. The status of women's leadership in Malaysia enterprises also reflects that women leaders have made great progress on the academic knowledge, women leaders has made great progress on leadership, and women leaders deviation to the recognizes of leadership will also influence the leadership. After the analysis the relationship between dimensions of leadership effectiveness and women leadership and the relationship among four dimensions of leadership effectiveness, through analysis the factor of women leadership and survey from female senior managers, the most influential factors of female leadership has been found. Therefore, the recommendation of improving the effectiveness of women leadership has been put forward. The recommendations are mainly proposed from four aspects such as management level, women leader themselves, enterprise level and social environment level.

In conclusion, the majority of senior women leaders are middle aged women with a stable family and grown up children. Usually they have light family burden and have enough energy and time to organize the work, stretches their managerial ability; plus accumulated several years of working experience and management capabilities. It can better reflect the superiority of women's leadership. The effectiveness of leadership is the important indicators of women's leadership. There has been diversity between women leaders from different age, education level, years of managerial experience and types of enterprises. Women with different demographic background will show different in leadership. Glass ceiling effect, job satisfaction, moral characters and organisational citizenship behaviour are the four important dimensions of leadership effectiveness. Women leadership can be affected by glass ceiling effect, moral characters and organisational citizenship behaviour, moral characters are the main influential factor of women's leadership. However, according to research analysis, job satisfaction shows seldom relationship on women's leadership.

Generally speaking, women leaders in senior management level still take small proportion compared to men. Compared to state-owned enterprises or large enterprises, women's leadership has considered more successful in small and medium-sized enterprises (Teoh \& Chong, 2008). In addition, these four dimensions are only the typical dimensions of leadership effectiveness that related to women leadership. According to the previous researches and studies, there are many other factors that relate to women's leadership, such as women leaders' turnover intention, organisational and social perception to women.

With the progress of society, women begins play more and more important role in all fields of society, especially in the enterprises. With more advancement of women leaders, it is urgent for women leaders to strengthen their professional skills and working abilities, improve their moral standards and values, to adapt to the changing and challenging leadership environment, and make a greater contribution to enterprises. 


\section{References}

Abdul, G. A., Syed, I. S. H., \& Basir, S. A. (2011). Career Advancement Barriers in Malaysian Federal Public Service. International Conference on Financial Management and Economics, 11. Retrieved from http://www.ipedr.com/vol11/62-W10019.pdf

Aziri, B. (2011). Job Satisfaction: A Literature Review. Management Research and Practice, 3(4).

Azlan, A. B. (2009). Move to develop 4,000 women entrepreneurs by 2012. World of Malaysian SMEs. Retrieved from http://smeblog.nst.com.my/2009/12/move-to-develop-4000-women.html

Barsh, J., \& Yee, L. (2011). Unlocking the full potential of women in the US economy. McKinsey \& Company. Retrieved from http://www.mckinsey.com/client_service/organization/latest_thinking/unlocking_the_full_potential

Bass, B. M. (1990). Bass \& Stogdill's Handbook of Leadership: Theory, Research \& Managerial Applications. United States: Free Press.

Bass, B. M., \& Riggio, R. E. (2006). Transformational Leadership (2nd ed.). New Jersey: Lawrence Erlbaum Associates, Inc.

Bennetts, L. (2012). Women and the Leadership Gap. The Newsweek/Daily Beast Company. Retrieved from http://www.thedailybeast.com/newsweek/2012/03/04/the-stubborn-gender-gap.html

Berkwits, M., \& Inui, T. S. (1998). Making Use of Qualitative Research Techniques. Journal of General Internal Medicine, 13(3).

Bilimoria, D., \& Piderit, S. K. (2007). Handbook on Women in Business and Management. United Kingdom: Edward Rlgar Publishing Limited.

Bloomberg Business Week. (2010). Women Leaders: The Hard Truth about Soft Skills. Companies \& Industries Retrieved

from http://www.businessweek.com/stories/2010-02-16/women-leaders-the-hard-truth-about-soft-skillsbusinessw eek-business-news-stock-market-and-financial-advice

Brief, B. (2011). Lessons from female leaders in professional service firms" Bain \& Company. Retrieved from http://www.bain.com/publications/articles/lessons-from-female-leaders-in-professional-service-firms.aspx

Bronwynne, B. (2007). Fresh Perspectives: Managing People. Charlotte Imani: Pearson Education South Africa, Ltd.

Brown, G., \& Irby, B. J. (2001). Women and Leadership: Creating Balance in Life. New York: Nova Science Publishers, Inc.

Buddhapriya, S. (1999). Women in Management. New Delhi: A. P. H. Publishing Corporation.

Burke, R. J., \& Mattis, M. C. (2007). Women and Minorities in Science, Technology, Engineering, and Mathematics. UK: Edward Elgar Publishing Limited.

Buttell, M. (2010). Female leaders at an advantage. HP Management. Retrieved from http://www.hrmreport.com/news/female-leaders-advantage/

Chmiel, M. (2001). Elie Wiesel and the politics of moral leadership. United States: Temple University Press.

Ciulla, J. B. (2004). Ethics, the Heart of Leadership. United States: Greenwood Publishing Group, Inc.

Connor, K. (2010). Gender and Women's Leadership: A Reference Handbook. United Kingdom: SAGE publication, Inc.

Daft, R. L. (2008). The Leadership Experience (4th ed.). USA: Thomson South-Western.

Deanne, N., \& Hartog, D. (2001). Handbook of Industrial, Work \& Organizational Psychology. Organizational Psychology, 2. London: Sage Publications Ltd.

Desvaux, G., \& Devillard, S. (2008). Women Matter 2- Female leadership, a competitive edge for the future. McKinsey \& Company, Inc. Retrieved http://curt-rice.com/2012/01/23/women-matter-2-female-leadership-a-competitive-edge-for-the-future/

Eagly, A. H. (2007). Female Leadership Advantage and Disadvantage: Resolving the Contradictions. Psychology of Women Quarterly, 31. USA: Blackwell Publishing, Inc.

Eagly, A. H., \& Johannesen-Schmidt, M. C. (2001). The Leadership Styles of Women and Men. Journal of 
Social Issues, 57(4).

Eagly, A. H., \& Steffen, V. J. (1986). Gender and Aggressive Behavior: A Meta-Analytic Review of the Social Psychological Literature. Psychological Bulletin, 100(3).

Eikelenboom, B. (2005). Organizational Capabilities and Bottom Line Performance. Eburon: B.L. Eikelenboom.

Farh, J., Zhong, C. B., \& Organ, D. W. (2004). Organsational Citizenship Behaviour in China. Organisational Science, 15(2).

Fisher, H. E. (1999). The first sex: The natural talents of women and how they are changing the world. Michigan University: Random House.

Friedman, H. H. (2001). Moral Leadership: Ancient Lessons for Modern Times. The Journal of Leadership Studies, $7(2)$.

Furness, H. (2012). Women are more moral than men, survey says. Retrieved from http://www.telegraph.co.uk/science/science-news/9206176/Women-are-more-moral-than-men-survey-says. $\mathrm{html}$

Gordon, T. (2002). Leader Effectiveness Training. New York: The Berkley Publishing Group.

Grace, N. (2012). Why Good Moral Character Is Needed in the Workplace. Hearst Newspapers. Retrieved from http://smallbusiness.chron.com/good-moral-character-needed-workplace-30969.html

Greasley, P. (2008). Quantitative Data Analysis with SPSS. New York: McGraw-Hill.

Hartog, D. D., \& Koopman, P. (2001). Leadership in Organizations. Work \& Organizational Psychology, 2. Retrieved from http://www.sagepub.com/northouseintro2e/study/chapter/handbook/handbook4.1.pdf

Harzing, A. W., \& Pinnington, A. (2011). International Human Resource Management (3rd ed.). London: SAGE Publications Ltd.

Heilman, M., Wallen, A., Fuchs, D., \& Tamkins, M. (2004). Penalties for Success: Reactions to Women Who Succeed at Male Gender-Typed Tasks. Journal of Applied Psychology, 89(3).

Joseph, E. E., \& Winston, B. E. (2005). A correlation of servant leadership, leader trust, and organizational trust. Leadership \& Organization Development Journal, 26(1).

Kaputa, C. (2009). The Female Brand: Using the Female Mind set to Succeed in Business. USA: Nicholas Brealey Publishing.

Kelley, L. D., \& Jugenheimer, D. W. (2008). Advertising Media Planning: A brand management approach (2nd ed.). New York: M. E. Sharpe, Inc.

Koneck, G. M. (2006). A Study of Women Leadership Styles and the Glass Ceiling. United States: Capella University.

Lemons, M. A. (2003). Contextual and Cognitive Determinants of Procedural Justice Perceptions in Promotion Barriers for Women. Kluwer Academic Publishers-Plenum Publishers, 49(5).

Li, L. (2011). Research Evaluation of Construction Studies Abroad on Job Performance. International Conference on Future Computer Science and Education.

Maimunah, I. (1996). Gender needs analysis of women entrepreneurs. Pertanika Journal of Social Science and Humanities, 4(1).

Manning, G., \& Curtis, K. (2003). The art of leadership. New York: The McGraw-Hill Companies, Inc.

Mattis, M. C. (2001). Advancing women in business organizations: Key leadership roles and behaviours of senior leaders and middle managers. Journal of Management Development, 20(4).

May, C. (2012). Are Men Less Moral Than Women? Studies Show Ethical Standards. HuffPost Women. Retrieved from http://www.huffingtonpost.com/2012/06/19/men-less-moral-women-ethical-standards_n_1609426.html

McKinsey \& Company. (2012). Women Matter: Making the breakthrough. McKinsey Organization: Client Service Retrieved from http://www.mckinsey.com/client_service/organization/latest_thinking/women_matter

Mehrotra, A. (2005). Leadership Styles of Principals. New Delhi: Krishan Mittal for Mittal Publications.

Mele, D. (2011). Management Ethics: Placing Ethics at the Core of Good Management. Domenec Mele: 
Palgrave Macmillan.

Mester, C. A. (2003). Leadership style and its relation to employee attitudes and behavior. Journal of Industrial Psychology, 29(2).

Morgan, D. L., Krueger, R. A., \& King, J. A. (1998). Developing Questions for Focus Groups. Thousand Oaks: SAGE Publications Ltd.

Munzel, G. F. (1999). Kant's Conception of Moral Character. London: The University of Chicago Press, Ltd.

Murray, R. (2010). Cracking the Highest Glass Ceiling: A Global Comparison of Women's Campaigns for Executive Office. USA: Rainbow Murray.

Organ, D. W., Podsakoff, P. M., \& Mackenzie, S. B. (2006). Organizational Citizenship Behaviour: Its Nature, Antecedents, and Consequences. United States: Sage Publications, Inc.

Organisation for Economic Cooperation and Development (OECD). (2012). The Business Case for Women's Economic Empowerment. The Voice of OECD Business. Retrieved from http://www.biac.org/members/elsa/mtg/2012-02-workshop/OECD_Background_Paper_for_the_Worksho.p df

Pande, R., \& Ford, D. (2011). Gender Quotas and Female Leadership. World Development Report. Retrieved from http://siteresources.worldbank.org/INTWDR2012/Resources/7778105-1299699968583/7786210-13226717 73271/Pande-Gender-Quotas-April-2011.pdf

Podsakoff, P. M., \& Mackenzie, S. B. (2000). Organizational Citizenship Behaviours: A Critical Review of the Theoretical and Empirical Literature and Suggestions for Future Research. Journal of Management, 26(3). Retrieved

from http://myweb.usf.edu/ jdorio/Organizational\%20citizenship\%20behaviors $\% 20 \mathrm{a} \% 20$ critical $\% 20$ review $\% 20$ of $\% 20$ the $\% 20$ theoretical $\% 20$ and $\% 20$ empirical $\% 20$ literature $\% 20$ and $\% 20$ suggestions $\% 20$ for $\% 20$ future $\% 20$ research.pdf

Reeves, D. B. (2006). The Dimensions of Leadership. Association for Supervision and Curriculum Development. Retrieved from http://www.ascd.org/publications/books/105151/chapters/The-Dimensions-of-Leadership.aspx

Saari, L. M., \& Judge, T. A. (2004). Employee Attitudes and Job Satisfaction. Human Resource Management, 43(4). Retrieved from http://utm.edu/staff/mikem/documents/jobsatisfaction.pdf

Schneider, B., \& Smith, D. B. (2004). Personality and organizations. Taylor Francies-Library: Lawrence Erlbaum Associates, Inc.

Scott, K. G. (2008). Transcendental Leadership: The Impact of Spirituality on the Effectiveness of Women Small Business Owners. United States: ProQuest Information and Learning Company.

Shannon, D. M. (2000). Using SPSS(R) to Solve Statistical Problems: A Self-Instruction Guide. Upper Saddle River: Prentice-Hall, Inc.

Sledgehammer Communications. (2012). Women in Leadership Asia 2012 Awards Shortlist. Retrieved from http://adoimagazine.com/index.php/awards/170-awards-watch-2012/7610-women-in-leadership-asia-2012awards-shortlist- [Accessed on 17/03/2013]

SME Corp. (2011). Women Entrepreneurs. Retrieved from http://www.smeinfo.com.my/index.php?option=com_content\&view=article\&id=1154\&Itemid=1112

Snowdon, G. (2011). Women still face a glass ceiling. The Guardian. Retrieved from http://www.guardian.co.uk/society/2011/feb/21/women-glass-ceiling-still-exists-top-jobs

Spector, P. E. (1997). Job satisfaction: application, assessment, cause, and consequences. University of Michigan: Sage Publications.

Stark, M., \& Ely, R. J. (2003). Women Leaders and Organizational Change. Harvard Business School Working Knowledge. Retrieved from http://hbswk.hbs.edu/item/3796.html

Sugerman, J. (2011). The 8 Dimensions of Leadership: DiSC Strategies for Becoming a Better Leader (1st ed.). California: Berrett-Koehler Publishers, Inc.

Süssmuth-Dyckerhoff, C., Wang, J., \& Chen, J. (2011). Women Matter: An Asian Perspective. McKinsey \& Company. Retrieved from http://www.mckinseychina.com/2012/07/02/women-matter-an-asian-perspective/ 
Tayyab, S. (2005). Organisational Citizenship Behaviour: Validating Factorial Structure and Invariance among Employees. Journal of the Indian Academy of Applied Psychology, 31(1).

Teoh, W., \& Chong, S. (2008). Improving Women Entrepreneurs in Small and Medium Enterprises in Malaysia: Policy Recommendations. Communications of the IBIMA, 2.

Tewfik, S. (2011). Women's Participation in Educational Leadership: A Survey Study of Factors Affecting Women's Participation in Educational Leadership in Addis Ababa, Ethiopia. VDM Publishing

Toegel, G. (2010). The state of women's leadership. IMD Real World, Real Learning. Retrieved from http://www.imd.org/research/challenges/TC064-10.cfm

Tong, Z. Y. (2004). Women's leadership and the flexible management. Leading Science, 20.

Tu, M. C. (2006). Culture and Job Satisfaction. United States: ProQuest Information and Learning Company.

Turesky, E. F., Cloutier, K. S., \& Turesky, M. F. (2011). Feminine Paths to Leadership in Italy: Perceptions of Female Italian Leaders in a Masculine Society. Integral Leadership Review. Retrieved from $\mathrm{http} / /$ integralleadershipreview.com/3995-feminine-paths-to-leadership-in-italy-perceptions-of-female-italia n-leaders-in-a-masculine-society

Turkel, C. C. (2008). Female Leaders' 360-degree Self-perception Accuracy for Leadership Competencies and Skills. UMI: ProQuest Information and Learning Company.

Valerio, A. M. (2011). Developing Women Leaders: A Guide for Men and Women in Organizations. United Kingdom: John Wiley \& Sons.

Van Vianen, A. E. M., \& Fischer, A. H. (2002). Illuminating the glass ceiling: The role of organizational culture preferences. Journal of Occupational \& Organizational Psychology, 75(3).

Vondey, M. (2010). The Relationships among Servant Leadership, Organizational Citizenship Behavior, Person-Organization Fit, and Organizational Identification. Journal of Leadership Studies, 6(1).

Weber, L. (1998). A Conceptural Framework for Understanding Race, Class, Gender, and Sexuality. Psychology of Women Quarterly, 22. Retrieved from http://ed-share.educ.msu.edu/scan/ead/mwawrzyn/Weber.pdf

Wharton, A. S., \& Baron, J. N. (1991). Satisfaction? The Psychological Impact of Gender Segregation on Women at work. Sociological Quarterly, 32(3).

Wood, G. J., \& Jogulu, U. D. (2006). Malaysian and Australian Male and Female Middle Managers. International Journal of Knowledge, Culture and Chance Management, 6(3).

Woods, P. (2006). Qualitative Research. Retrieved from http://www.edu.plymouth.ac.uk/resined/qualitative\%20methods\%202/qualrshm.htm

Young, J. J. (2011). Leadership Styles and Gender Role: Internalization among Female Managers in the United States. Advancing Women in Leadership, 31.

\section{Copyrights}

Copyright for this article is retained by the author(s), with first publication rights granted to the journal.

This is an open-access article distributed under the terms and conditions of the Creative Commons Attribution license (http://creativecommons.org/licenses/by/3.0/). 